\title{
鼻腔通気性に及ぼす運動の影響に関する研究
}

\author{
東京医科歯科大学医学部耳鼻咽喉科学教空（主任：渡辺 勈教授） \\ 大 木 幹 文
}

\section{EFFECTS OF EXERCISE ON NASAL PATENCY}

MOTOFUMI OHKI, M.D.

Department of Otolaryngology, Faculty of Medicine, Tokyo Medical and Dental University, Tokyo

Congestion and decongestion of the nasal mucosa are induced by many factors, including the spontaneous nasal cycle, changes in the breathing pattern, posture, temperature, humidity, and exercise. Among these, exercise is considered to have an intensive effect on nasal patency. The effect of exercise on nasal patency was assessed in 70 children (aged six to 15 years) and 92 adults (aged 16 to 38 years). Five children were normal. 15 had allergic rhinitis, and had asthma. There were 26 normal adults, and 66 adults had allergic rhinitis. All patients performed a six-minute treadmill exercise test. Nasal resistances were measured at a pressure of $1.0 \mathrm{~cm}$ water by anterior rhinomanometry before and immediately after exercise, as well as 5, 10, 15, 20, 25 and 30 minutes after exercise. The $\mathrm{FEV}_{1}$ was also determined in children. Exercise-induced decreases in nasal resistance were observed in all subjects immediately after exercise ; the decrease was marked in patients with allergic rhinitis. Nasal resistance values immediately after exercise were comparable in normal subjects and in those with allergic rhinitis. In patients with allergic rhinitis and asymmetrical skeletal abnormalities of the nose, exercise reduced the difference between the right and left nasal resistance values observed initially; however, a difference remained. In general, nasal resistance began to recover about five minutes after exercise. However, post-exercise nasal resistance values tended to be higher than pre-exercise levels, especially in patients with allergic rhinitis. Extreme increases in nasal resistance, ie, "exercise induced nasal obstruction," were observed in 15 of 66 (23\%) adults and 6 of 15 (40\%) children with allergic rhinitis and in 18 of $50(36 \%)$ children with asthma. In children with asthma, there was no significant correlation between the occurrence of "exercise-induced nasal obstruction" and "exercise-induced asthma". None of the normal subjects experienced "exercise-induced nasal obstruction."

"Exercise-induced nasal obstruction" is indicative in clarifying the congestion process of allergic nasal mucosa reacting to non-specific stimuli.

Key words : 鼻腔抵抗, 運動負荷, 鼻アレルギー, 運動誘発鼻閉

A $91-1419-32822$

1.はじめに

鼻疾患の診断及び治療を考える際, 鼻壁の通気性は,
非常に大きな問題である. 鼻粘膜は安静状態において も常に一定の状態に保たれている訳ではなく変化して 
いる、事実, 激しい運動をした後やまわりの, 気温, 湿度などにより，鼻の通気性の変化を実感する人は， 正常人においても少なくない.これらの変化は, 自律 神経によって制御された血行動態の変化によるものと 考えられている ${ }^{122) 3)}$ ．鼻腔の通気性に影響を与える因 子は多数あるが，大別すると，構造性因子（骨格性因 子）と，粘膜性因子に分けることができる(1)56). 構造性 因子とは，鼻中隔あるいは甲介骨の形態によるもので あり，固定しており通気性の変化をひきおこさない. 一方, 粘膜性の因子は粘膜の変化に影響を与える因子 て，鼻粘膜の分泌抢よび鼻粘膜の腫脹収縮に関与し， 鼻の通気性の変化を与えるものである。

この粘膜性因子としては，Nasal $\mathrm{Cycle}^{7 / 23)}$ ，姿

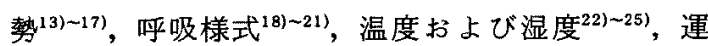
動2324226)2728) などが知られているが，中でも，運動は， 最も鼻腔の通気性に著しい変化を与える因子と考えら れている ${ }^{29)}$.また, 気管支喘息患者においては, 運動し た後に一過性に喘息発作をおこす，いわゆる運動誘発 喘息（Exercise-induced asthma，EIA）という現象が 知られている ${ }^{30)}$.このように, 運動は，上気道および下 気道の呼吸動態に興味ある影響を及浔すものと考えら れる。しかしながら，これまでの運動による鼻空の通 気性に関する研究においては，そのほとんどが，運動 直後のものであり, 運動負荷後の鼻粘膜の変化に関す る報告は少ない。また，鼻腔の通気度の測定方法につ いても，十分に信頼性のある方法であったとは言えな い.ところが，1970年代に入り，鼻腔通気度計の開発 により, 鼻の通気性の変化を客観的に, より正確に測 定することが可能となった ${ }^{31}$.そこで,正常者, および, 鼻アレルギー患者, 小児気管支喘息患者に対し運動負 荷を行い，鼻腔抵抗を鼻腔通気度計により測定するこ とにより，運動が鼻粘膜に対しどのような影響を及ほ すのかについて，検討を行ってみた。

\section{2. 対象}

今回対象としたのは，6歳〜15歳までの小児と，16 歳〜38墄までの成人である，小児群としては，正常児 5 名 (女肾 5 名)，気管支喘息児 50 名，小児鼻アレルギ 一患者（気管支喘息を伴わない）15名である．成人群 としては，正常成人26名 (男性16名, 女性10名)，鼻ア レルギー患者66名（男性29名，女性37名）である，身 アレルギー患者は，事前に，鼻鏡検查，アレルダン皮 内テスト，RIST, RAST を行い，通年性か，季節性か の別を調べ，季節性鼻アレルギー患者に対しては，検
査時期として，発作期を選んだ。気管支喘息児におい ては，アレルゲン皮内テスト，RIST，RASTを行い， 検査は，喘息非発作時期に行った。なお，鼻アレルギ 一患者，気管支喘息児に関しては，患者あるいは家族 $に$ 十分検查の有用性を説明し，同意を得，検査前24恃 間の間，一切の投薬，治療を中止した。

\section{3. 方法}

(1) 運動量による鼻腔抵抗の変化の検討（成人） 正常成人 26 名のうち, 男 7 名，女 5 名に対し，日本 光電製のトレッドミルを用い, 時速 $6 \mathrm{~km}$, 傾斜 $10 \%$ の 運動負荷を行い，同一人に負荷時間を 2 分，4分，6 分間と変えて, 運動負荷試験を施行し, その前後の鼻 腔抵抗の変化を記録した。この際， 3 種の負荷試駼施 行にあたっては，最低48時間の間隔をあけ，また，娜 定にあたっては，座位にて30分以上の安静を保った後， 行った。鼻腔抵抗の測定は，日本光電製 Rhinorheograph, MPR1100にてノズルを用いた Anterior 法(前 方誘導法) で, 左右の圧一流速曲線 (鼻腔通気度曲線) を描かせ，呼気時における $\mathrm{P}=1.0 \mathrm{cmH}_{2} \mathrm{O}$ の基準点に おける鼻腔抵抗を測定した。測定は各々，負荷前，負 荷直後, 5 分, 10 分, 15 分, 20 分, 25 分, 30 分後に行 った．全鼻腔抵抗の算出に関しては

$1 /$ 全鼻腔抵抗 $=1 /$ 右側鼻腔抵抗 $+1 /$ 左側鼻腔抵抗 の式を用い圧差 $\mathrm{P}=1.0 \mathrm{cmH}_{2} \mathrm{O}$ における左右の鼻腔 抵抗值から算出した. なお, 測定時の室温は, 21 24으. 湿度は40〜60\%であった。

（2）運動負荷（6 分）と鼻腔抵抗との相互関係の椧 討（成人）

次に, 正常成人 26 名, 成人鼻アレルギー患者 66 名に, 方法(1)と同様，トレッドミルにて，傾斜 $10 \%, 6 \mathrm{~km} / \mathrm{h}$, 6 分間の運動負荷を行い, 負荷前, 負荷直後, 5 分, 10分, 15分, 20分, 25分, 30分後の鼻腔抵抗を测定し た. 測定方法は，すべて，方法(1)と同一条件下て行っ た.

（3）運動負荷の鼻腔抵抗および下気道におよ涩す影 響（小児）

正常児 5 名，気管支喘息児50名，小児鼻アレルギー 患者15名に方法(1)と同一条件下に，トレッドミルにて， 傾斜 $10 \%, 6 \mathrm{~km} / \mathrm{h}, 6$ 分間の運動負荷を行い, 負荷前, 負荷直後, 4 分, 9 分, 14 分, 19分, 24 分, 29 分後の 鼻腔抵抗を湘定した。 また，負荷前，負荷直後，5分， 10分, 15分, 20 分, 25 分, 30 分後に, フクダ電子製の スパイロメータを用いて，1秒量 $\left(\mathrm{FEV}_{1.0}\right)$ を測定し， 


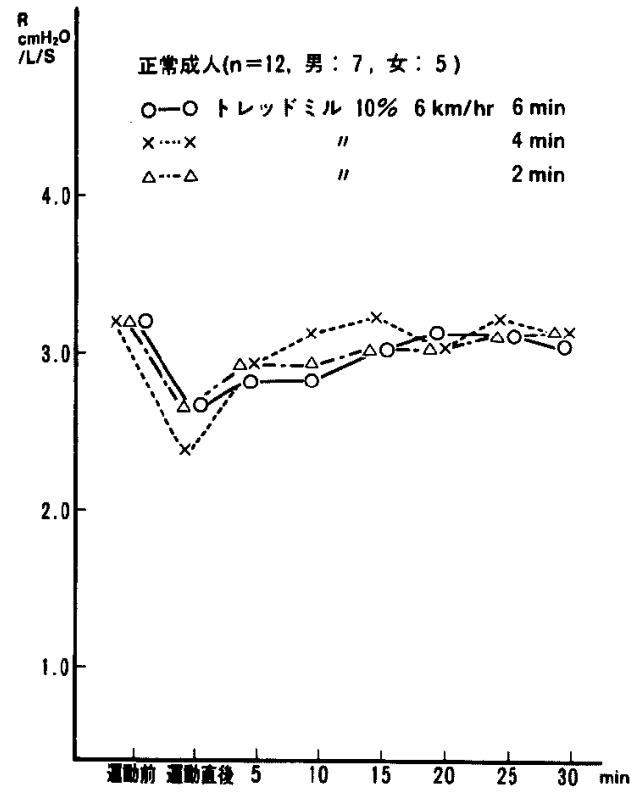

図 1 運動負荷時間に上る全鼻腔抵抗変化の 比較

運動が下気道に及ぼす影響を検討した，1秒量測定に あたっては，鼻をクリップするので鼻空抵抗測定を毎 回 1 秒量測定の 1 分前に行った.

\section{4. 結果}

(1) 運動量による鼻腔抵抗の変化（成人）

正常成人 12 名の, 2 分, 4 分, 6 分の運動負荷試験 の結果は図 1 に示す通りである。この3 回の運動負荷 前の座位安静時の全鼻腔抵抗には, 有意の差は認めら れなかった，一定の運動負荷を行うと，直後には全鼻 燃抵抗は低下し，その值は，2 分，4分，6分に颃い て，それぞれ，元の值の70〜80\%に低下した．その後， 5 分後には, 安静時の鼻腔抵抗に戻る傾向を示した。 15〜20分後には，安静時の鼻腔抵抗值にほぼ等しくな る. 30分後までの経過をみると, 安静時の鼻腔抵抗值 より極端に大きくなる例はみられなかった。

2 分, 4 分, 6 分と運動量を变えた時の, 運動直後 の全鼻腔抵抗值の割合はあまり変わらず，その後の全 鼻腔抵抗の変化はあまり変わりはなかった。

（2）運動負荷 ( 6 分) と鼻腔抵抗の相互関係 (成人)

(a) 運動々全鼻腔抵抗

正常成人 26 名と, 成人鼻アレルギー患者 66 名の, 運 動負荷による鼻腔抵抗の変化を表 $1,2 ， 3 ， 4$ に示
した，図 $2 \mathrm{a} ， \mathrm{~b}$ は，全鼻腔抵抗の変化ちよび，その 順位変換 (Rank Transformation) である. その処理 は, Fleiss $(1986)^{32)}$, Conover \& Iman $(1981)^{33)}$, 佐 久間 $(1987)^{34)}$ らの解析方法に従って行った. 反復測定 によるデータの分散分析の結果, 正常成人群, 成人鼻 アレルギー群と時間の交互作用は， $\mathrm{P}=0.0014$ で, 有 意差が認められた。すなかち，両群のプロフィールを 比較してみると, 安静時の鼻空抵抗は正常成人群に対 し，成人鼻アレルギー患者では，高い傾向にある。一 方, 正常成人群执よび, 成人鼻アレルギー患者群にお いて，6 分間の運動負荷をかけると, その直後では全 鼻腔抵抗は，雨者七も有意に低下した。その低下率は, 正常成人では $20 \%$ ，成人鼻アレルギー患者では， $40 \%$ となり,このことから, 全鼻腔抵抗は, 運動により正 常成人と成人鼻アレルギー患者では，ほほ等しい值を 示す結果となった５分後になると運動により低下し た全鼻羫抵抗は, 正常群, 鼻アレルギー群とも,すで に, 元に戻りはじめる. 続いて, 15〜20分後には, 正 常成人では, 安静時の鼻腔抵抗值の近隣で安定するの に対し, 鼻アレルギー群では, 舅腔抵抗の戻り方が, ダイナミックであり,むしろ, 安静時の鼻腔抵抗より 有意に大きくなって行く傾向がみられた（図 2 a).

(b) 運動と片側鼻腔抵抗

運動をすると, その直後には, 左右の鼻腔抵抗のい ずれも低下するが，その低下の割合は，左右では必ず しも一致しない(図 3 ). 正常成人 26 名の鼻腔抵抗值の 左右差を求めてみると, 安静時には, $4.0 \pm 3.5 \mathrm{cmH}_{2} \mathrm{O} /$ L/Sであったものが, 運動直後には, $1.0 \pm 0.7 \mathrm{cmH}_{2} \mathrm{O} /$ L/S となった.すなわち, 左右鼻粘膜の腫脹側と収縮 側とを比較すると, 運動により, 腫脹側の方がより収 縮しやすいことを示した，従って，正常成人では運動 負荷を行うと,左右の鼻腔抵抗值がほほ等しくなった。 一方, 成人鼻アレルギー患者の鼻腔抵抗值の左右差は, 安静時 $10.6 \pm 11.0 \mathrm{cmH}_{2} \mathrm{O} / \mathrm{L} / \mathrm{S}$, 運動直後には $2.5 \pm$ $3.1 \mathrm{cmH}_{2} \mathrm{O} / \mathrm{L} / \mathrm{S}$ であった。この結果は, 成人鼻アレル ギー群が正規性にとぼしいことを意味する。そこで， 66名の鼻アレルギ一患者を鼻中隔彎曲などの鼻腔骨格 形態異常を伴った17名と，伴わない49名とに分けて， 鼻腔抵抗值の左右差の累積分布曲線を, 安静時および, 運動負荷直後について，描いた。その結果を図 $4 \mathrm{a}$, bに示す，鼻腔骨格形態異常の有無は，2名の耳鼻咽 喉科医の一致によりくだした，図 $4 \mathrm{a}, \mathrm{b} の 2$ 群の交 点は, それぞれ $9.8 \mathrm{cmH}_{2} \mathrm{O} / \mathrm{L} / \mathrm{S}, 2.4 \mathrm{cmH}_{2} \mathrm{O} / \mathrm{L} / \mathrm{S}$ とな った。さらに，両者の運動負荷前後の鼻腔抵抗值を線 
表 1 正常成人の運動負荷前後の全鼻腔抵抗の変化（単位： $\mathrm{cmH}_{2} \mathrm{O} / \mathrm{L} / \mathrm{S}$ )

\begin{tabular}{|c|c|c|c|c|c|c|c|c|c|c|c|c|c|c|c|c|c|c|c|c|c|c|c|}
\hline 番早 & 民名 & 年命 & 性别 & 连的㧧 & 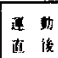 & 5 分後 & 10 分理 & 15分俊 & 20 年得 & 25分楼 & 30分传 & $6 \frac{7}{5}$ & 氏 8 & 年令 & 性别 & 滥加前 & 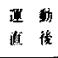 & 5 分得 & 10 分课 & 15 年傮 & 203 集 & 25 得 & 30 年 \\
\hline 1 & K.T. & 29 & $\mathrm{M}$ & 4.0 & 3.2 & 3.5 & 3.1 & 4.2 & 3.5 & 3.5 & 4.4 & 14 & M.O. & 31 & $M$ & 3.0 & 1.9 & 2.3 & 2.7 & 2.6 & 3.1 & 3.6 & 3.7 \\
\hline 2 & H.X. & 17 & M & 2.9 & 2.3 & 2.9 & 3.1 & 3.4 & 2.8 & 3.2 & 3.1 & 15 & М.H. & 20 & $M$ & 1.5 & 1.0 & 1.1 & 1.4 & 1.5 & 1.6 & 1.7 & 1.6 \\
\hline 3 & I.Y. & 23 & M & 2.1 & 2.5 & 2.9 & 2.9 & 2.3 & 1.8 & 2.2 & 2.8 & 16 & Y.1. & 26 & $\mathbf{F}$ & 3.1 & 2.3 & 5.3 & 3.9 & 3.1 & 3.2 & 3,3 & 3.5 \\
\hline 4 & T.M. & 24 & M & 2.4 & 2.5 & 2.6 & 3.1 & 3.3 & 2.9 & 2.5 & 3.0 & 17 & N.N. & 30 & $F$ & 4.8 & 3.9 & 4.4 & 4.2 & 4.4 & 4.2 & 4.2 & 4.4 \\
\hline 5 & J.W. & 26 & $M$ & 2.8 & 1.9 & 3.1 & 3.0 & 3.0 & 2.5 & 3.0 & 3.3 & 18 & M.N. & 22 & $M$ & 3.1 & 1.1 & 1.6 & 2.2 & 2.2 & 2.5 & 2.7 & 2.7 \\
\hline 6 & S.N. & 25 & $M$ & 3.4 & 2.7 & 2.9 & 2.6 & 2.7 & 3.0 & 3.0 & 2.7 & 19 & K.H. & 30 & $F$ & 3.2 & 2.7 & 2.4 & 2.1 & 2.5 & 1.8 & 1.8 & 2.3 \\
\hline 7 & G. I. & 23 & $\mathrm{M}$ & 3.9 & 3.0 & 3.7 & 3.4 & 3.7 & 4,0 & 3.4 & 2.7 & 20 & $Y . A$. & 25 & $\mathrm{~F}$ & 1.9 & 1.8 & 1.8 & 1.9 & 2.1 & 2.3 & 2.3 & 1.9 \\
\hline 8 & J.M. & 24 & $\mathbf{M}$ & 2.6 & 2.3 & 2.3 & 2.4 & 2.4 & 2.1 & 2.5 & 2.7 & 21 & Y. 1. & 24 & $F$ & 3.7 & 3.9 & 3.9 & 4.4 & 5.0 & 5.0 & 4.8 & 5.0 \\
\hline 9 & M.M. & 25 & $M$ & 2.6 & 2.0 & 1.6 & 1.4 & 1.6 & 1.7 & 1.7 & 1.9 & 22 & A.H. & 22 & $F$ & 2.8 & 2.4 & 2.5 & 2.2 & 2.4 & 2.5 & 3.6 & 1.0 \\
\hline 10 & G.N. & 25 & $\mathrm{M}$ & 4.0 & 1.9 & 2.2 & 2.5 & 2.2 & 2.2 & 2.4 & 2.4 & 23 & X.F. & 22 & $\mathrm{~F}$ & 3.4 & 3.2 & 2.9 & 2.6 & 2.6 & 4.0 & 3.2 & 3.1 \\
\hline 11 & M.K. & 20 & $\mathrm{M}$ & 3.0 & 2.9 & 2.9 & 2.6 & 3.1 & 2.6 & 2.4 & 2.4 & 24 & K.T. & 21 & $F$ & 4.4 & 3.2 & 3.7 & 4.4 & 4.8 & 4.5 & 4.2 & 1.2 \\
\hline 12 & I.Y. & 20 & $M$ & 2.5 & 2.6 & 2.7 & 2.4 & 2.4 & 2.5 & 2.5 & 2.5 & 25 & H.K. & 23 & $\mathbf{F}$ & 2.1 & 1.9 & 2.5 & 2.2 & 2.3 & 2.9 & 2.5 & 2.5 \\
\hline 13 & C.S. & 22 & $F$ & 4.3 & 2.9 & 3.9 & 3.5 & 3.2 & 3.3 & 4.2 & 4.2 & 26 & H.T, & 23 & $\mathrm{M}$ & 4.0 & 1.8 & 2.0 & 1.7 & 2.2 & 2.7 & 3.7 & 3.7 \\
\hline
\end{tabular}

表 2 正常成人の運動急荷前後の片側鼻腔抵抗の変化

(上段：左鼻腔，下段：右鼻腔，単位 $\mathrm{cmH}_{2} \mathrm{O} / \mathrm{L} / \mathrm{S}$ )

\begin{tabular}{|c|c|c|c|c|c|c|c|c|c|c|c|c|c|c|c|c|c|c|c|c|c|c|c|}
\hline 排䇾 & $\mathbb{A} y_{i}$ & 年合 & 许: 斿 & 䔩FH & 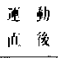 & 5 你识 & 10分传 & 15 分滛 & 20 多缕 & $25 \sin \pi$ & 305 俀 & 湆 & 民: & 年命 & 竹别 & 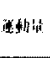 & 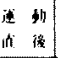 & 5 份缕 & 10 卉後 & 15 㘯谈 & 20分淩 & 25 放列 & 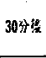 \\
\hline \multirow{2}{*}{1} & \multirow{2}{*}{ K.T. } & \multirow{2}{*}{29} & \multirow{2}{*}{$M$} & 5.3 & 5.8 & 4.4 & 4.0 & 5.0 & 4.2 & 3.9 & 6.3 & \multirow{2}{*}{14} & \multirow{2}{*}{ M.O. } & \multirow{2}{*}{31} & \multirow{2}{*}{$M$} & 3.9 & 3.5 & 4.0 & 5.9 & 5.6 & 8.3 & 7.7 & 12.5 \\
\hline & & & & 16.7 & 7.1 & 16.7 & 14.3 & 25.0 & 20.0 & 33.3 & 14.3 & & & & & 12.5 & 4.2 & 5.3 & 5.0 & 5.0 & 5.0 & 6.7 & 5.3 \\
\hline \multirow{2}{*}{2} & \multirow{2}{*}{ H.Y. } & \multirow{2}{*}{17} & \multirow{2}{*}{$\mathrm{M}$} & 9.1 & 4.2 & 7.1 & 8.3 & 7.1 & 5.3 & 7.1 & 6.7 & \multirow{2}{*}{15} & \multirow{2}{*}{ M.H. } & \multirow{2}{*}{20} & \multirow{2}{*}{$\mathrm{M}$} & 2.2 & 2.2 & $2 . ?$ & 4.2 & 4.4 & 4.5 & 5.6 & 5.7 \\
\hline & & & & 4.3 & 5.3 & 5.0 & 5.0 & 6.7 & 5.9 & 5.9 & 5.9 & & & & & 4.5 & 1.9 & 1.9 & 2.1 & 2.2 & 2.4 & 2.4 & 2.3 \\
\hline \multirow{2}{*}{3} & \multirow{2}{*}{ I.Y. } & \multirow{2}{*}{23} & \multirow{2}{*}{$M$} & 3.1 & 5.0 & 5.6 & 5.0 & 3.6 & 3,4 & 3.3 & 5.0 & \multirow{2}{*}{16} & \multirow{2}{*}{$\mathrm{Y}, \mathrm{L}$. } & \multirow{2}{*}{26} & \multirow{2}{*}{ F } & 40 & 4.0 & 7.3 & 7.7 & 7.1 & 7.7 & 8.1 & 8.1 \\
\hline & & & & 6.7 & 5.0 & 5.9 & 6.3 & 6.3 & 4.0 & 6.7 & 6.3 & & & & & 14.3 & 5.6 & 16.7 & 7.7 & 5.6 & 5.6 & 5,6 & 6.3 \\
\hline 4 & $T M$ & 24 & $M$ & 6.3 & 5.3 & 4.3 & 7.1 & 5.6 & 5.0 & 3.6 & 4.2 & 17 & $N \mathrm{~N}$ & 30 & $F$ & 7.7 & 7.7 & 12.5 & 12.5 & 12.5 & 14.3 & 14.3 & 14.3 \\
\hline 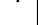 & T.1. & 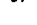 & $m$ & 4.0 & 4.8 & 6.3 & 5.6 & 8.3 & 7.1 & 10.0 & 10.0 & 21 & Son & 00 & t & 12.5 & 7.7 & 6.7 & 6.3 & 6.7 & 5.9 & $5.9^{\circ}$ & 6.3 \\
\hline 5 & 1w & 26 & $M$ & 6.7 & 5.3 & 10.0 & 10.0 & 11.1 & 16.7 & 16.7 & 14.3 & 18 & $\mathrm{YM}$ & 97 & & 9.1 & 3.1 & 3.2 & 3.3 & 3.3 & 4.0 & 4.5 & 4.5 \\
\hline . & $0 .$. & s. & . & 4.8 & 2.9 & 4.5 & 43 & 4.2 & 2.9 & 3.6 & 4.3 & to & 19.18. & 22 & 100 & 4.8 & 1.7 & 3.1 & 6.7 & 6.7 & 6.7 & 6.7 & 6.7 \\
\hline 6 & 5. & 25 & $M$ & 6.7 & 5.9 & 6.3 & 7.1 & 7.7 & 7.7 & 6.7 & 7.7 & 19 & $\mathrm{~K} \mathrm{~K}$ & 30 & $F$ & 9.1 & 6.3 & 5.3 & 6.7 & 4.8 & 4.5 & 4.5 & 5.0 \\
\hline 0 & 0.1 & wa & $m$ & 7.1 & 5.0 & 5.3 & 4.0 & 4.2 & 5.0 & 5.3 & 4.2 & 10 & 1 & . & . & 5.0 & 4.8 & 4.5 & 3.1 & 5.3 & 3.0 & 3.0 & 6.2 \\
\hline 7 & G. & 23 & $M$ & 7.7 & 6.7 & 1.7 & 5.9 & 5.3 & 7.7 & 5.9 & 4.0 & 70 & $\gamma A$ & 25 & $F$ & 3.1 & 3.0 & $3 ?$ & 42 & 3.4 & 4.0 & 4.0 & 3.1 \\
\hline ? & (5). & 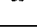 & $m$ & 7.7 & 5.6 & 3.1 & 8.3 & 12.5 & 8.3 & 8.3 & 8.3 & 20 & T & 20 & 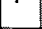 & 4.8 & 4.5 & 4.0 & 3.6 & 5.3 & 5.6 & 5.6 & 4.8 \\
\hline 8 & $\triangle \mathrm{M}$ & 24 & $M$ & 6.7 & 4.5 & 3.0 & 3.2 & 3.1 & 2.7 & 3.3 & 3.7 & 21 & $Y$ & 28 & $F$ & 7.1 & 7.7 & 5.5 & 5.9 & 7.7 & 6.7 & 7.7 & 8.3 \\
\hline 0 & s.tine & $-\infty$ & & 4.2 & 4.5 & 9.1 & 10.0 & 10.0 & 10.0 & 10.0 & 10.5 & 27 & 151 & 24 & 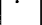 & 7.7 & 7.7 & 12.5 & 16.7 & 14.3 & 20.0 & 12.5 & 12.5 \\
\hline 9 & $M M$ & 25 & $M$ & 4.5 & 5.0 & 3.3 & 2.6 & 2.8 & 3.8 & 4.0 & 3.7 & 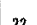 & 4 & ?n & $\mathrm{F}$ & 5.9 & 4.2 & 5.3 & 3.7 & 4.2 & 4.2 & 6.3 & 7.7 \\
\hline 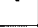 & 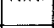 & 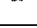 & $m$ & 5.9 & 3.2 & 3.1 & 2.9 & 4.0 & 3.1 & 2.9 & 3.8 & 26 & Into & 22 & 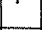 & 5.3 & 5.6 & 4.8 & 5.3 & 3.6 & 5.9 & 8.3 & 8.3 \\
\hline 10 & $G . N$ & 25 & $M$ & 9.1 & 4.2 & 4.3 & 5.9 & 5.3 & 5.3 & 6.3 & 5,9 & 23 & $\mathrm{KK} F$ & 22 & $F$ & 4.6 & 5.6 & 3.7 & 3.7 & 3.5 & 5.0 & 4.0 & 4.0 \\
\hline 100 & & 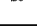 & & 7.1 & 3.6 & 4.5 & 4.3 & 3.8 & 3.8 & 4.0 & 3.9 & 20 & Ro. & 26 & $r$ & 12.5 & 7.7 & 12.5 & 9.1 & 10.0 & 20.0 & 16.7 & 14.3 \\
\hline 11 & M.K. & 20 & $M$ & 7.7 & 6.7 & 6.7 & 5,6 & 6.7 & 4.5 & 4.5 & 4.5 & 24 & K.T. & 21 & $F$ & 16.7 & 6.3 & 7.1 & 7.7 & 9.1 & 10.0 & 7.1 & 1.1 \\
\hline & & & & 4.8 & 5.0 & 5.0 & 5.0 & 5.6 & 6.3 & 5.0 & 5.0 & 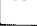 & & 121 & 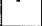 & 5.9 & 6.3 & 7.1 & 10.0 & 10.0 & B. 3 & 10,0 & 10.0 \\
\hline 12 & I.Y. & 20 & M & 7.7 & 5.0 & 5.3 & 6.7 & 6.3 & 7.7 & 7.7 & 7.7 & 25 & I H K & 23 & $\mathbf{F}$ & 4.0 & 3.6 & 4.6 & 4.2 & 5.0 & 5.6 & 5.0 & 4.0 \\
\hline & & & & 3.7 & 5.3 & 5.3 & 3.8 & 4.0 & 3.7 & 3.7 & 3.7 & 20 & I & 200 & 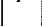 & 4.6 & 4.2 & 5.6 & 4.6 & 4.4 & 5.9 & 5.0 & 2.1 \\
\hline 13 & C.S. & 22 & $F$ & 8.3 & 5.6 & 6.3 & 5.6 & 5.6 & 5.6 & 7.1 & 7.1 & 76 & H T & 23 & $M$ & 14.3 & 4.5 & 3.3 & 3.6 & 5.6 & 8.3 & 9.1 & 9.1 \\
\hline 100 & 0.01 & $\ldots$ & 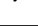 & 9.1 & 5.9 & 10.0 & 9.1 & 7.7 & B. 3 & 10.0 & 10.0 & 20 & 11. & 20 & 10 & 5.6 & 2.9 & 4.8 & 3.3 & 3.6 & 4.0 & 6.3 & 6.3 \\
\hline
\end{tabular}


表 3 鼻アレルギー患者の運動負荷前後の全鼻腔抵抗の変化（単位： $\mathrm{cmH}_{2} \mathrm{O} / \mathrm{L} / \mathrm{S}$ )

\begin{tabular}{|c|c|c|c|c|c|c|c|c|c|c|c|c|c|c|c|c|c|c|c|c|c|c|c|}
\hline 霖节 & 民名 & 年角 & tot & 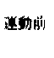 & 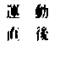 & 5 放传 & 10方浌 & 15你被 & $20 \sin$ & 25st传 & 305 话 & 舟烈 & If & 年令 & 牛:别 & 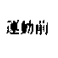 & $\begin{array}{ll}4 & 5 \\
\text { tit } & \text { if }\end{array}$ & 5 分得 & 10stik & 15你 & 20 trit & 25分得 & 30 万传 \\
\hline 1 & S.F. & 19 & $F$ & 4.8 & 1.9 & 3.6 & 3.2 & 2.7 & 3.0 & 3.4 & 3.2 & 34 & K.K. & 19 & $F$ & 3.7 & 2.4 & 2.4 & 6.1 & 4.0 & 5.9 & 4.0 & 5.3 \\
\hline 2 & T.N. & 22 & $M$ & 3.2 & 2.3 & 2.8 & 2.9 & 3.0 & 2.9 & 3.3 & 3.0 & 35 & M.M. & 36 & $\mathrm{~F}$ & 3.9 & 2.8 & 3.8 & 4.4 & 3.5 & 3.7 & 3.6 & 3.6 \\
\hline 3 & A. I. & 24 & $M$ & 3.0 & 2.0 & 2.0 & 2.1 & 2.6 & 3.5 & 2.4 & 2.6 & 36 & T.K. & 16 & $F$ & 2.9 & 1.9 & 3.0 & 4.3 & 3.7 & 3.8 & 5.0 & 3.7 \\
\hline 4 & T T. & 38 & $M$ & 5.0 & 2.6 & 3.4 & 3.6 & 4.2 & 4.0 & 3.6 & 3.6 & 37 & $Y . A$. & 17 & $M$ & 6.7 & 2.6 & 2.1 & 1.9 & 2.5 & 3.0 & 1.0 & 4,0 \\
\hline 5 & HI I, & 25 & $\mathrm{~F}$ & 4.6 & 2.1 & 3.3 & 4.0 & 4.1 & 4.3 & 4.1 & 4.8 & $3 B$ & M. 0 & 37 & $F$ & 2.7 & 2.6 & 2.2 & 1.9 & 2.1 & 2.1 & 2.0 & 2.7 \\
\hline 6 & S.S. & 34 & $\mathrm{~F}$ & 8.3 & 3.0 & 5.6 & 5.3 & 12.5 & 11.1 & 9.7 & 9.1 & 39 & M.A. & 16 & $F$ & 4.4 & 1.5 & 2.2 & 3.4 & 3.7 & 4.4 & 5.3 & 5.0 \\
\hline 7 & Y.K. & 22 & $M$ & 8.3 & 1.7 & 1.7 & 1.9 & 2.0 & 2.0 & 2.4 & 2.3 & 40 & N.U. & 20 & $F$ & 2.3 & 2.1 & 2.4 & 2.5 & 2.2 & 2.8 & 2.8 & 2.9 \\
\hline 8 & $H: K$. & 25 & $F$ & 5.9 & 3.9 & 6.2 & 16.7 & 6.7 & 11.1 & 10.0 & 10.0 & 41 & N.M. & 23 & $F$ & 3.0 & 1.9 & 2.4 & 3.6 & 5.2 & 7.1 & 6.3 & 5.9 \\
\hline 9 & A. T. & 19 & $M$ & 2.3 & 2.1 & 3.9 & 5.9 & 4.3 & 4.6 & 4.6 & 4.6 & 42 & K.S. & 24 & $\mathrm{~F}$ & 3.4 & 2.5 & 3.1 & 3.9 & 4.4 & 4.1 & 4.4 & 4.4 \\
\hline 10 & T.N. & $26^{\circ}$ & $M$ & 2.8 & 1.5 & 2.9 & 3.8 & 3.2 & 2.9 & 3.5 & 2.9 & 43 & Y.Y. & 27 & $M$ & 5.6 & 3.9 & 3.7 & 4.5 & 6.7 & 5.3 & 4.4 & 4.6 \\
\hline 11 & T.S. & 29 & $\mathrm{~F}$ & 3.0 & 2.6 & 2.9 & 2.7 & 3.2 & 3.2 & 4.2 & 3.2 & 44 & M.H. & 17 & M & 2.9 & 2.1 & 2.3 & 2.5 & 5.9 & 5.9 & 11.1 & 16.7 \\
\hline 12 & K.H. & 25 & $F$ & 2.8 & 1.8 & 2.5 & 3.0 & 2.2 & 3.9 & 3.0 & 3.3 & 45 & M.K. & 29 & $M$ & 4.5 & 2.8 & 2.4 & 2.5 & 2.9 & 3.0 & 3.3 & 4.2 \\
\hline 13 & S.H. & 30 & $F$ & 2.6 & 2.6 & 4.8 & 4.0 & 4.5 & 45 & 3.4 & 3.4 & 46 & H.K. & 27 & $F$ & 2.8 & 2.5 & 2.6 & 3.4 & 2.8 & 4.4 & 3.9 & 3.9 \\
\hline 14 & Y.Y. & 31 & $\mathrm{~F}$ & 5.6 & 2.9 & 2.8 & 2.4 & 3.0 & 3.6 & 4.3 & 5.0 & 47 & M.D. & 19 & $F$ & 10,0 & 5.2 & 9.1 & 9.5 & 14.3 & 14.3 & 11.1 & 16.7 \\
\hline 15 & K.S. & 16 & $M$ & 6.7 & 2.3 & 4.0 & 4.2 & 5.1 & 5.3 & 5.6 & 5.9 & 48 & F.W. & 33 & $F$ & 2.9 & 1.5 & 1.7 & 2.0 & 2.1 & 2.3 & 2.3 & 2.5 \\
\hline 16 & Y.M. & 31 & $F$ & 5.9 & 1.8 & 4.3 & 4.7 & 3.9 & 3.5 & 3.9 & 3.9 & 49 & M.S. & 22 & $M$ & 4.4 & 4.0 & 1.1 & 6.9 & 9.1 & 4.6 & 4.4 & 4.6 \\
\hline 17 & K.T. & 24 & $M$ & 2.9 & 2.2 & 2.6 & 3.2 & 2.5 & 2.1 & 2.4 & 2.2 & 50 & K.K. & 24 & $\mathrm{~F}$ & 6.6 & 3.0 & 5.5 & 8.3 & 6.3 & 10.0 & 7.7 & 6.7 \\
\hline 18 & M.M. & 18 & $F$ & 4.0 & 1.8 & 2.5 & 2.6 & 4.5 & 3.5 & 4.4 & 4.1 & $\$ 1$ & M.M. & 16 & $M$ & 2.3 & 1.4 & 2.3 & 1.9 & 1.8 & 2.6 & 3.2 & 2.4 \\
\hline 19 & S.Y. & 16 & $F$ & 10.0 & 5.0 & 7.1 & 8,3 & 8.3 & 11.1 & 10.5 & 10.5 & 52 & T.o. & 32 & $M$ & 2.5 & 1.9 & 2.5 & 2.7 & 2.5 & 2.6 & 2.9 & 2.7 \\
\hline 20 & A.T. & 27 & $M$ & 20.0 & 3.7 & 25.0 & 50.0 & 50.0 & 100.01 & 100.01 & $100.0 \mathrm{~T}$ & 53 & $\mathrm{Y} . \mathrm{K}$ & 28 & $M$ & 3.1 & 2.6 & 2.9 & 3.0 & 2.9 & 3.1 & 3.2 & 3.2 \\
\hline 21 & T.N. & 24 & $M$ & 3.3 & 2.9 & 1.9 & 2.3 & 2.8 & 4,6 & 4.6 & 4.0 & 54 & C.T & 22 & $F$ & 4.4 & 2.2 & 2.7 & 2.5 & 2.0 & 2.4 & 2.8 & 2.3 \\
\hline 22 & K.S. & 22 & $M$ & 3.8 & 2.4 & 3.0 & 2.9 & 2.9 & 3.0 & 3.0 & 3.0 & 55 & K.K. & 25 & $\mathrm{~F}$ & 4.2 & 2.0 & 2.5 & 3.4 & 4.0 & 4.8 & 5.0 & 4.2 \\
\hline 23 & T.T. & 16 & $M$ & 6.2 & 4.4 & 3.3 & 7.1 & 3.5 & 3.9 & 4.2 & 4.4 & 56 & s.o. & 19 & $M$ & 2.5 & 1.8 & 2.3 & 2.0 & 2.5 & 2.4 & 2.8 & 2.5 \\
\hline 24 & A.M. & 26 & $M$ & 4.8 & 2.7 & 5.0 & 3.3 & 4.8 & 4.0 & 3.1 & 3.7 & 57 & M.Y. & 19 & $M$ & 5.0 & 1.5 & 2.1 & 3.2 & 3.4 & 4.0 & 4.8 & 5.0 \\
\hline 25 & K.M. & 2] & $F$ & 5.6 & 2.7 & 5.9 & 5.3 & 4.2 & 6.3 & 4.2 & 4.8 & 58 & T.M. & 23 & $M$ & 3.1 & 2.3 & 4.2 & 4.2 & 3.6 & 3.4 & 3.6 & 4.8 \\
\hline 26 & H.K. & 26 & $F$ & 1.9 & 1.4 & 1.6 & 2.0 & 1.8 & 1.8 & 1.5 & 1.9 & 59 & M.T. & 19 & $F$ & 3.9 & 2.3 & 2.9 & 3.7 & 4.8 & 3.3 & 3.6 & 4.0 \\
\hline 27 & M.K. & 19 & $F$ & 7.1 & 7.7 & 7.1 & 14.3 & 25.0 & 25.0 & $100.0 \uparrow$ & $100.0 \uparrow$ & 60 & M.O. & 26 & $M$ & 4.8 & 2.7 & 5.0 & 3.3 & 4.8 & 4.0 & 3.1 & 3.7 \\
\hline 28 & I.K. & 20 & $\mathrm{~F}$ & 5.0 & 2.2 & 1.0 & 3.7 & 5.3 & 6.3 & 7.1 & 9.1 & 61 & H.o. & 25 & $M$ & 2.0 & 1.7 & 1.9 & 2.1 & 1.9 & 2.2 & 2.3 & 2.5 \\
\hline 29 & K.E. & 36 & $\mathbf{F}$ & 3.0 & 2.8 & 3.8 & 4.3 & 3.4 & 3.4 & 3.6 & 3.7 & 62 & H.F. & 25 & $M$ & 3.1 & 2.1 & 4.0 & 3.9 & 3.9 & 4.8 & 3.6 & 4.8 \\
\hline 30 & M.K. & 20 & $F$ & 4.2 & 2.8 & 2.8 & 3.6 & 3.7 & 3.5 & 3.5 & 2.9 & 63 & A.O. & 21 & $F$ & 3.6 & 2.4 & 2.4 & 3.7 & 4.0 & 5.9 & 4.7 & 5.3 \\
\hline 31 & R. 0 . & 37 & $F$ & 2.8 & 2.1 & 2.3 & 2.1 & 2.2 & 2.4 & 2.5 & 2.6 & 64 & S.K. & 17 & $\mathrm{~F}$ & 2.4 & 1.7 & 2.0 & 3.0 & 3.0 & 2.6 & 3.1 & 3.1 \\
\hline 32 & H.T. & 35 & F & 2.4 & 2.1 & 2.1 & 2.6 & 2.7 & 3.7 & 4.0 & 3.9 & 65 & H.H. & 24 & $\mathrm{~F}$ & 10.0 & 2.6 & 5.0 & 5.9 & 8.4 & 16.7 & 16.7 & 20.0 \\
\hline 33 & S.s. & 23 & $M$ & 4.2 & 2.4 & 3.4 & 5.0 & 3.8 & 5.6 & 5.1 & 4.6 & 66 & $\mathbf{N}, \mathbf{N}$ & 25 & $M$ & 1.5 & 1.2 & 1.9 & 1.8 & 1.9 & 2.2 & 2.5 & 3.1 \\
\hline
\end{tabular}


表 4 鼻アレルギー患者の運動負荷前後の片側鼻腔抵抗の変化 （上段：左鼻腔，下段：右鼻腔，単位： $\mathrm{cmH}_{2} \mathrm{O} / \mathrm{L} / \mathrm{S}$ )

\begin{tabular}{|c|c|c|c|c|c|c|c|c|c|c|c|c|c|c|c|c|c|c|c|c|c|c|c|}
\hline 典 & it 8 & 4. & tit: & 眾为前 & 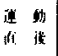 & 5 s the & 106万人坛 & 15 s & 20 多 & 25 斿 & 30 年谣 & 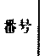 & 氏 $\%$ & 篻会 & t) & 䢤为的 & 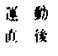 & 5 分传 & 10分楼 & 15分機 & 20 方徎 & 25份摞 & 3047 偖 \\
\hline I & S.F. & 19 & $\mathrm{~F}$ & $\begin{array}{r}16.7 \\
6.7\end{array}$ & $\begin{array}{l}3.6 \\
4.2\end{array}$ & $\begin{array}{r}4.0 \\
33.3\end{array}$ & $\begin{array}{r}3.5 \\
33.3\end{array}$ & $\begin{array}{r}3.0 \\
25.0\end{array}$ & $\begin{array}{r}3.5 \\
20.0\end{array}$ & $\begin{array}{r}3.6 \\
50.0\end{array}$ & $\begin{array}{r}3.5 \\
33.3\end{array}$ & 34 & K.K. & 19 & $\mathrm{~F}$ & $\begin{array}{l}6.3 \\
9.1\end{array}$ & $\begin{array}{l}5.3 \\
4.5\end{array}$ & $\begin{array}{l}4.0 \\
5.9 \\
\end{array}$ & $\begin{array}{l}14.3 \\
10.5\end{array}$ & $\begin{array}{l}7.7 \\
8.3\end{array}$ & $\begin{array}{r}20.0 \\
8.3\end{array}$ & $\begin{array}{r}12.5 \\
5.9\end{array}$ & $\begin{array}{r}8.3 \\
14.3\end{array}$ \\
\hline 2 & T.N. & 22 & $M$ & $\begin{array}{r}12.5 \\
4.3\end{array}$ & $\begin{array}{l}5.3 \\
4.0\end{array}$ & $\begin{array}{r}11.1 \\
3.8 \\
\end{array}$ & $\begin{array}{l}9.1 \\
4.3\end{array}$ & $\begin{array}{r}10.0 \\
4.3 \\
\end{array}$ & $\begin{array}{l}9.1 \\
4.3 \\
\end{array}$ & $\begin{array}{r}12.5 \\
4.5 \\
\end{array}$ & $\begin{array}{r}10.0 \\
4.3 \\
\end{array}$ & 35 & M.M. & 36 & $\mathrm{~F}$ & $\begin{array}{r}5.6 \\
12.5 \\
\end{array}$ & $\begin{array}{l}4.3 \\
7.7 \\
\end{array}$ & $\begin{array}{l}7.1 \\
8.3 \\
\end{array}$ & $\begin{array}{r}7.7 \\
10.0 \\
\end{array}$ & $\begin{array}{l}7.7 \\
6.3 \\
\end{array}$ & $\begin{array}{r}5.6 \\
11.1 \\
\end{array}$ & $\begin{array}{r}5.6 \\
18.0 \\
\end{array}$ & $\begin{array}{c}5.6 \\
10.0\end{array}$ \\
\hline 3 & A.1. & 24 & $M$ & $\begin{array}{r}16.7 \\
3.7\end{array}$ & $\begin{array}{l}5.3 \\
3.3\end{array}$ & $\begin{array}{l}4.6 \\
3.5\end{array}$ & $\begin{array}{l}4.4 \\
4.0\end{array}$ & $\begin{array}{l}5.9 \\
4.8\end{array}$ & $\begin{array}{l}6.3 \\
7.7\end{array}$ & $\begin{array}{l}4.8 \\
4.8\end{array}$ & $\begin{array}{l}5.0 \\
5.6\end{array}$ & 36 & T.K. & 16 & $\mathrm{~F}$ & $\begin{array}{r}33.3 \\
3.2 \\
\end{array}$ & $\begin{array}{l}5.6 \\
2.9 \\
\end{array}$ & $\begin{array}{r}16.7 \\
3.6 \\
\end{array}$ & $\begin{array}{r}33.3 \\
5.0\end{array}$ & $\begin{array}{r}33.3 \\
4.2\end{array}$ & $\begin{array}{r}100.0 \\
4.0\end{array}$ & $\begin{array}{r}50.0 \\
5.6\end{array}$ & $\begin{array}{r}50.0 \\
4.0\end{array}$ \\
\hline 4 & T.T. & 36 & M & $\begin{array}{l}10.0 \\
10.0\end{array}$ & $\begin{array}{l}6.3 \\
4.3\end{array}$ & $\begin{array}{l}6.7 \\
7.1\end{array}$ & $\begin{array}{l}7.7 \\
6.7\end{array}$ & $\begin{array}{l}8.3 \\
8.3\end{array}$ & $\begin{array}{l}7.7 \\
8.3\end{array}$ & $\begin{array}{l}6.7 \\
7.7\end{array}$ & $\begin{array}{l}6.7 \\
7.7\end{array}$ & 37 & Y.A. & 17 & $M$ & $\begin{array}{r}33.3 \\
7.1 \\
\end{array}$ & $\begin{array}{l}5.6 \\
5.0 \\
\end{array}$ & $\begin{array}{l}5.3 \\
3.6 \\
\end{array}$ & $\begin{array}{l}5.6 \\
2.9 \\
\end{array}$ & $\begin{array}{l}7.1 \\
4.8 \\
\end{array}$ & $\begin{array}{l}4.5 \\
9.1 \\
\end{array}$ & $\begin{array}{r}6.3 \\
11.1 \\
\end{array}$ & $\begin{array}{r}6.3 \\
11.1\end{array}$ \\
\hline 5 & H. I. & 25 & $F$ & $\begin{array}{r}5.3 \\
33.3 \\
\end{array}$ & $\begin{array}{l}4.1 \\
4.2 \\
\end{array}$ & $\begin{array}{r}4.6 \\
11.1 \\
\end{array}$ & $\begin{array}{r}4.6 \\
33.3 \\
\end{array}$ & $\begin{array}{r}4.7 \\
33.3 \\
\end{array}$ & $\begin{array}{r}4.7 \\
50.0 \\
\end{array}$ & $\begin{array}{r}4.5 \\
50.0 \\
\end{array}$ & $\begin{array}{r}5.0 \\
100.0 \\
\end{array}$ & 38 & M.o. & 37 & $\mathrm{~F}$ & $\begin{array}{l}5.0 \\
5.9 \\
\end{array}$ & $\begin{array}{l}4.5 \\
5.9 \\
\end{array}$ & $\begin{array}{r}4.5 \\
4.3 \\
\end{array}$ & $\begin{array}{l}4.0 \\
3.7 \\
\end{array}$ & $\begin{array}{l}3.4 \\
5.3 \\
\end{array}$ & $\begin{array}{l}4.5 \\
3.8 \\
\end{array}$ & $\begin{array}{l}4.3 \\
3.7 \\
\end{array}$ & $\begin{array}{l}5.9 \\
5.0 \\
\end{array}$ \\
\hline 6 & S.S. & 34 & $\mathrm{~F}$ & $\begin{array}{l}25.0 \\
12.5\end{array}$ & $\begin{array}{l}7.1 \\
5.0\end{array}$ & $\begin{array}{l}12.5 \\
10.0\end{array}$ & $\begin{array}{r}20.0 \\
7.1\end{array}$ & $\begin{array}{r}100.0 \\
14.3 \\
\end{array}$ & $\begin{array}{l}100.0 \\
12.5 \\
\end{array}$ & $\begin{array}{r}100.0 \\
10.7 \\
\end{array}$ & $\begin{array}{r}100.0 \\
10.0 \\
\end{array}$ & 39 & M.A. & 16 & $\mathrm{~F}$ & $\begin{array}{r}5.3 \\
25.0 \\
\end{array}$ & $\begin{array}{l}3.2 \\
2.7 \\
\end{array}$ & $\begin{array}{l}8.3 \\
3.0 \\
\end{array}$ & $\begin{array}{r}50.0 \\
3.7 \\
\end{array}$ & $\begin{array}{r}50.0 \\
4.0 \\
\end{array}$ & $\begin{array}{r}100.0 \\
4.6 \\
\end{array}$ & $\begin{array}{r}100.0 \\
5.6 \\
\end{array}$ & $\begin{array}{c}100.01 \\
5.0 \\
\end{array}$ \\
\hline 7 & Y.K. & 22 & $M$ & $\begin{array}{l}12.5 \\
25.0 \\
\end{array}$ & $\begin{array}{l}4.0 \\
3.1 \\
\end{array}$ & $\begin{array}{l}3.7 \\
3.0 \\
\end{array}$ & $\begin{array}{c}100.09 \\
1.9 \\
\end{array}$ & $\begin{array}{c}100.01 \\
2.0 \\
\end{array}$ & $\begin{array}{c}100.01 \\
2.0\end{array}$ & $\begin{array}{c}100.0^{\circ} \\
2.4 \\
\end{array}$ & \begin{tabular}{|c|}
100.01 \\
2.3 \\
\end{tabular} & 40 & N.U. & 20 & $F$ & $\begin{array}{l}3.8 \\
5.9 \\
\end{array}$ & $\begin{array}{l}4.5 \\
3.8 \\
\end{array}$ & $\begin{array}{l}7.1 \\
3.7 \\
\end{array}$ & $\begin{array}{l}5.9 \\
4.2 \\
\end{array}$ & $\begin{array}{l}7.1 \\
3.1 \\
\end{array}$ & $\begin{array}{l}8.3 \\
4.2 \\
\end{array}$ & $\begin{array}{l}8.3 \\
4.2 \\
\end{array}$ & $\begin{array}{l}9.1 \\
4.2\end{array}$ \\
\hline 8 & H.K. & 25 & $F$ & $\begin{array}{l}10.0 \\
14.3\end{array}$ & $\begin{array}{l}9.1 \\
5.1\end{array}$ & $\begin{array}{l}14.3 \\
11.1\end{array}$ & \begin{tabular}{|l|}
33.3 \\
33.3 \\
\end{tabular} & $\begin{array}{l}11.1 \\
16.7\end{array}$ & $\begin{array}{l}20.0 \\
25.0\end{array}$ & $\begin{array}{l}16.7 \\
25.0 \\
\end{array}$ & $\begin{array}{l}16.7 \\
25.0 \\
\end{array}$ & 41 & N.M. & 23 & $\mathrm{~F}$ & $\begin{array}{l}5.9 \\
6.3 \\
\end{array}$ & $\begin{array}{l}3.8 \\
4.0 \\
\end{array}$ & $\begin{array}{l}4.0 \\
5.9 \\
\end{array}$ & $\begin{array}{r}5.6 \\
10.0 \\
\end{array}$ & $\begin{array}{r}8.3 \\
14.3 \\
\end{array}$ & $\begin{array}{l}12.5 \\
16.7 \\
\end{array}$ & $\begin{array}{l}12.5 \\
12.5 \\
\end{array}$ & \begin{tabular}{|l|}
11.1 \\
12.5 \\
\end{tabular} \\
\hline 9 & A.T. & 19 & M & $\begin{array}{r}33.3 \\
2.5 \\
\end{array}$ & $\begin{array}{l}5.9 \\
3.2 \\
\end{array}$ & $\begin{array}{r}4.2 \\
50.0 \\
\end{array}$ & $\begin{array}{r}6.7 \\
50.0 \\
\end{array}$ & $\begin{array}{r}4.5 \\
100.0 \\
\end{array}$ & $\begin{array}{r}4.8 \\
100.0 \\
\end{array}$ & $\begin{array}{r}4.8 \\
100.0 \\
\end{array}$ & $\begin{array}{r}4.8 \\
100.0 \\
\end{array}$ & 42 & K.S. & 24 & $F$ & $\begin{array}{r}4.5 \\
14.3 \\
\end{array}$ & $\begin{array}{r}3.2 \\
12.5 \\
\end{array}$ & $\begin{array}{r}3.7 \\
20.0 \\
\end{array}$ & $\begin{array}{r}4.2 \\
50.0 \\
\end{array}$ & $\begin{array}{c}4,5 \\
100,01 \\
\end{array}$ & $\begin{array}{c}4.2 \\
100.0 \dagger \\
\end{array}$ & $\begin{array}{c}4.5 \\
100.0 \% \\
\end{array}$ & $\begin{array}{c}1.5 \\
100.01 \\
\end{array}$ \\
\hline 10 & T.N. & 26 & $M$ & $\begin{array}{r}3.6 \\
12.5\end{array}$ & $\begin{array}{l}3.1 \\
2.9\end{array}$ & $\begin{array}{l}5.0 \\
6.7\end{array}$ & $\begin{array}{l}8.3 \\
7.1\end{array}$ & $\begin{array}{l}5.6 \\
7.7\end{array}$ & $\begin{array}{l}4.2 \\
9.1\end{array}$ & $\begin{array}{r}4.5 \\
16.7\end{array}$ & $\begin{array}{r}3.4 \\
20.0 \\
\end{array}$ & 43 & Y.Y. & $n$ & M & $\begin{array}{r}33.3 \\
6.7\end{array}$ & $\begin{array}{l}9.1 \\
6.7\end{array}$ & $\begin{array}{r}11.1 \\
5.6\end{array}$ & $\begin{array}{r}11.1 \\
7.7 \\
\end{array}$ & $\begin{array}{l}20.0 \\
10.0\end{array}$ & $\begin{array}{r}16.7 \\
7.7 \\
\end{array}$ & $\begin{array}{r}20.0 \\
5.6\end{array}$ & $\begin{array}{r}20.0 \\
5.9\end{array}$ \\
\hline 11 & T.S. & 29 & $\mathrm{~F}$ & $\begin{array}{l}6.7 \\
5.3\end{array}$ & $\begin{array}{l}5.0 \\
5.3\end{array}$ & $\begin{array}{l}7.1 \\
4.8 \\
\end{array}$ & $\begin{array}{l}7.7 \\
4.2\end{array}$ & $\begin{array}{l}7.1 \\
5.9 \\
\end{array}$ & $\begin{array}{l}8.3 \\
5.3 \\
\end{array}$ & $\begin{array}{r}11.1 \\
6.7 \\
\end{array}$ & $\begin{array}{l}8.3 \\
5.3 \\
\end{array}$ & 44 & $\mathrm{M} . \mathrm{H}$. & 17 & M & $\begin{array}{l}6.3 \\
5.3 \\
\end{array}$ & $\begin{array}{l}3.6 \\
5.0 \\
\end{array}$ & $\begin{array}{l}4.8 \\
4.5 \\
\end{array}$ & $\begin{array}{r}3.4 \\
10.0 \\
\end{array}$ & $\begin{array}{l}10.0 \\
14.3 \\
\end{array}$ & $\begin{array}{r}7.1 \\
33.3 \\
\end{array}$ & $\begin{array}{l}16.7 \\
33.3 \\
\end{array}$ & \begin{tabular}{|l|}
33.3 \\
33.3 \\
\end{tabular} \\
\hline 12 & K.H. & 25 & $\mathrm{~F}$ & $\begin{array}{l}4.2 \\
8.3\end{array}$ & $\begin{array}{l}2.9 \\
5.0\end{array}$ & $\begin{array}{l}4.0 \\
6.7\end{array}$ & $\begin{array}{l}4.5 \\
9.1\end{array}$ & $\begin{array}{l}3.4 \\
5.9\end{array}$ & $\begin{array}{r}5.6 \\
12.5\end{array}$ & $\begin{array}{l}4.8 \\
8.3\end{array}$ & $\begin{array}{r}4.5 \\
12.5\end{array}$ & 45 & M.K. & 29 & M & $\begin{array}{r}7.1 \\
12.5\end{array}$ & $\begin{array}{l}5.3 \\
5.9\end{array}$ & $\begin{array}{l}6.3 \\
4.0\end{array}$ & $\begin{array}{l}5.6 \\
5.0\end{array}$ & $\begin{array}{l}6.7 \\
5.0\end{array}$ & $\begin{array}{l}4.8 \\
7.7\end{array}$ & $\begin{array}{l}5.9 \\
7.7\end{array}$ & $\begin{array}{r}5.6 \\
16.7\end{array}$ \\
\hline 13 & S.H. & 30 & $\mathbf{F}$ & $\begin{array}{l}5.0 \\
5.3 \\
\end{array}$ & $\begin{array}{l}6.3 \\
4.5 \\
\end{array}$ & $\begin{array}{r}12.5 \\
7.7 \\
\end{array}$ & $\begin{array}{r}10.0 \\
6.7 \\
\end{array}$ & $\begin{array}{r}10.0 \\
8.3 \\
\end{array}$ & $\begin{array}{r}10.0 \\
8.3 \\
\end{array}$ & $\begin{array}{l}7.1 \\
6.7 \\
\end{array}$ & $\begin{array}{l}6.7 \\
6.7 \\
\end{array}$ & 46 & $\mathrm{H} . \mathrm{K}$. & 27 & $F$ & $\begin{array}{l}5.0 \\
6.3 \\
\end{array}$ & $\begin{array}{l}5.9 \\
4.2 \\
\end{array}$ & $\begin{array}{l}6.3 \\
4.5 \\
\end{array}$ & $\begin{array}{l}9.5 \\
5.3 \\
\end{array}$ & $\begin{array}{l}5.3 \\
5.9 \\
\end{array}$ & $\begin{array}{r}7.7 \\
10.0 \\
\end{array}$ & $\begin{array}{r}10.0 \\
6.3 \\
\end{array}$ & $\begin{array}{r}10.0 \\
6.3 \\
\end{array}$ \\
\hline 14 & $Y, Y$. & 31 & $\mathbf{F}$ & $\begin{array}{l}10.0 \\
12.5\end{array}$ & $\begin{array}{l}7.1 \\
4.8\end{array}$ & $\begin{array}{l}5.9 \\
5.3\end{array}$ & $\begin{array}{l}4.5 \\
5.0 \\
\end{array}$ & $\begin{array}{l}5.0 \\
7.7 \\
\end{array}$ & $\begin{array}{l}6.9 \\
7.7 \\
\end{array}$ & $\begin{array}{r}7.1 \\
11.1 \\
\end{array}$ & $\begin{array}{r}8.3 \\
12.5 \\
\end{array}$ & 47 & M.D. & $! 9$ & $F$ & $\begin{array}{l}33.3 \\
14.3 \\
\end{array}$ & $\begin{array}{l}11.0 \\
10.0\end{array}$ & $\begin{array}{l}14.3 \\
25.0 \\
\end{array}$ & $\begin{array}{l}15.4 \\
25.0\end{array}$ & $\begin{array}{l}50.0 \\
20.0\end{array}$ & $\begin{array}{l}50.0 \\
20.0 \\
\end{array}$ & \begin{tabular}{|l|}
50.0 \\
14.3 \\
\end{tabular} & $\begin{array}{l}50.0 \\
25.0 \\
\end{array}$ \\
\hline 15 & K.S. & 16 & $M$ & $\begin{array}{l}11.1 \\
16.7 \\
\end{array}$ & $\begin{array}{l}3.7 \\
6.3 \\
\end{array}$ & $\begin{array}{l}7.1 \\
9.1 \\
\end{array}$ & $\begin{array}{l}9.5 \\
7.4 \\
\end{array}$ & $\begin{array}{r}15.4 \\
7.7 \\
\end{array}$ & $\begin{array}{l}11.1 \\
10.0 \\
\end{array}$ & $\begin{array}{l}11.1 \\
11.1 \\
\end{array}$ & $\begin{array}{l}12.5 \\
11.1 \\
\end{array}$ & 48 & F.W. & 33 & $F$ & $\begin{array}{l}5.9 \\
5.6 \\
\end{array}$ & $\begin{array}{l}2.8 \\
3.1 \\
\end{array}$ & $\begin{array}{l}3.2 \\
3.7\end{array}$ & $\begin{array}{l}4.0 \\
4.2 \\
\end{array}$ & $\begin{array}{l}4.8 \\
3.6 \\
\end{array}$ & $\begin{array}{l}4.8 \\
4.5 \\
\end{array}$ & $\begin{array}{l}4.8 \\
4.3 \\
\end{array}$ & $\begin{array}{l}4.5 \\
5.6 \\
\end{array}$ \\
\hline 16 & Y.M. & 31 & $\mathrm{~F}$ & $\begin{array}{l}12.5 \\
11.1 \\
\end{array}$ & $\begin{array}{l}5.9 \\
2.6\end{array}$ & $\begin{array}{r}7.1 \\
11.1 \\
\end{array}$ & $\begin{array}{r}8.3 \\
11.1 \\
\end{array}$ & $\begin{array}{r}4.8 \\
20.0 \\
\end{array}$ & $\begin{array}{c}3.6 \\
100.0 \dagger \\
\end{array}$ & $\begin{array}{c}4.0 \\
100.09 \\
\end{array}$ & $\begin{array}{c}4.0 \\
100.01 \\
\end{array}$ & 49 & M.S. & 22 & $M$ & $\begin{array}{r}20.0 \\
5.6\end{array}$ & $\begin{array}{r}20.0 \\
5.0\end{array}$ & $\begin{array}{l}25.0 \\
10.0\end{array}$ & $\begin{array}{c}100.0 \uparrow \\
7.1\end{array}$ & $\begin{array}{r}100.0 \\
10.0\end{array}$ & $\begin{array}{r}5.6 \\
25.0\end{array}$ & $\begin{array}{r}5.6 \\
20.0 \\
\end{array}$ & $\begin{array}{r}3.5 \\
25.0 \\
\end{array}$ \\
\hline 17 & K.T. & 24 & M & $\begin{array}{l}5.0 \\
6.7 \\
\end{array}$ & $\begin{array}{l}5.0 \\
3.8\end{array}$ & $\begin{array}{l}7.1 \\
4.0 \\
\end{array}$ & $\begin{array}{l}6.3 \\
6.3 \\
\end{array}$ & $\begin{array}{l}6.3 \\
4.2 \\
\end{array}$ & $\begin{array}{l}5.3 \\
3.4 \\
\end{array}$ & $\begin{array}{l}5.6 \\
4.3 \\
\end{array}$ & $\begin{array}{l}6.7 \\
3.3\end{array}$ & 50 & K.K. & 24 & $\mathrm{~F}$ & $\begin{array}{r}3.3 \\
8.3\end{array}$ & $\begin{array}{r}12.5 \\
4.0\end{array}$ & $\begin{array}{r}16.7 \\
8.3\end{array}$ & \begin{tabular}{|l|}
11.1 \\
33.3
\end{tabular} & $\begin{array}{l}12.5 \\
12.5\end{array}$ & $\begin{array}{l}20.0 \\
20.0\end{array}$ & $\begin{array}{l}11.1 \\
25.0\end{array}$ & $\begin{array}{r}7.7 \\
59.0 \\
\end{array}$ \\
\hline 18 & M.M. & 18 & F & $\begin{array}{l}9.1 \\
7.1 \\
\end{array}$ & $\begin{array}{l}4.5 \\
2.9 \\
\end{array}$ & $\begin{array}{r}20.0 \\
2.9 \\
\end{array}$ & $\begin{array}{r}20.0 \\
3.0 \\
\end{array}$ & $\begin{array}{r}50.0 \\
5.0 \\
\end{array}$ & $\begin{array}{c}100.0 \uparrow \\
3.6 \\
\end{array}$ & $\begin{array}{c}100.01 \\
4.5 \\
\end{array}$ & $\begin{array}{c}100.01 \\
4.2\end{array}$ & 51 & M.M. & 16 & $M$ & $\begin{array}{l}3.1 \\
8.3 \\
\end{array}$ & $\begin{array}{l}.3 \\
2.5 \\
\end{array}$ & $\begin{array}{l}4.0 \\
5.3 \\
\end{array}$ & $\begin{array}{l}4.2 \\
3.6 \\
\end{array}$ & $\begin{array}{l}3.6 \\
3.6 \\
\end{array}$ & $\begin{array}{l}4.8 \\
5.6 \\
\end{array}$ & $\begin{array}{l}5.9 \\
7.1\end{array}$ & $\begin{array}{l}3.6 \\
7.1 \\
\end{array}$ \\
\hline 19 & S.Y. & 16 & $F$ & $\begin{array}{l}50.0 \\
12.5 \\
\end{array}$ & $\begin{array}{r}16.7 \\
7.1 \\
\end{array}$ & $\begin{array}{l}25.0 \\
10.0 \\
\end{array}$ & $\begin{array}{l}33.3 \\
11.1 \\
\end{array}$ & $\begin{array}{l}50.0 \\
10.0 \\
\end{array}$ & $\begin{array}{r}100.0 \\
12.5 \\
\end{array}$ & \begin{tabular}{c|}
100.01 \\
11.1 \\
\end{tabular} & $\begin{array}{c}100.01 \\
11.1\end{array}$ & 52 & T. 0 . & 32 & M & $\begin{array}{l}7.7 \\
3.7\end{array}$ & $\begin{array}{l}3.8 \\
3.7\end{array}$ & $\begin{array}{l}5.9 \\
4.3\end{array}$ & $\begin{array}{l}6.7 \\
4.5 \\
\end{array}$ & $\begin{array}{l}7.7 \\
3.8\end{array}$ & $\begin{array}{l}8.3 \\
3.8 \\
\end{array}$ & $\begin{array}{l}8.3 \\
4.5 \\
\end{array}$ & $\begin{array}{l}6.7 \\
6.5\end{array}$ \\
\hline 20 & A.T. & 27 & $M$ & $\begin{array}{l}33.3 \\
50.0 \\
\end{array}$ & $\begin{array}{r}14.3 \\
5.0 \\
\end{array}$ & $\begin{array}{l}50.0 \\
50.0 \\
\end{array}$ & $\begin{array}{l}100.0 \\
100.0 \\
\end{array}$ & $\begin{array}{l}100.01 \\
100.01\end{array}$ & $\begin{array}{l}100.0 \dagger \\
100.0 \dagger \\
\end{array}$ & \begin{tabular}{|l|}
100.01 \\
100,01 \\
\end{tabular} & $\begin{array}{l}100.01 \\
100.01\end{array}$ & 53 & $Y, K$. & 28 & M & $\begin{array}{l}6.7 \\
5.9\end{array}$ & $\begin{array}{l}7.1 \\
4.0\end{array}$ & $\begin{array}{l}7.1 \\
5.0\end{array}$ & $\begin{array}{l}7.7 \\
5.0\end{array}$ & $\begin{array}{l}7.7 \\
4.6\end{array}$ & $\begin{array}{l}7.7 \\
5.3\end{array}$ & $\begin{array}{l}7.1 \\
5.9\end{array}$ & $\begin{array}{l}1.7 \\
5.6 \\
\end{array}$ \\
\hline 21 & T.N. & 24 & $M$ & $\begin{array}{r}33.3 \\
3.7 \\
\end{array}$ & $\begin{array}{r}14.2 \\
3.7 \\
\end{array}$ & $\begin{array}{r}20.0 \\
2.1 \\
\end{array}$ & $\begin{array}{r}25.0 \\
2.5 \\
\end{array}$ & $\begin{array}{r}20.0 \\
3.3 \\
\end{array}$ & $\begin{array}{r}25.0 \\
5.6 \\
\end{array}$ & $\begin{array}{r}25.0 \\
5.6 \\
\end{array}$ & $\begin{array}{r}20.0 \\
5.0 \\
\end{array}$ & 54 & c. T. & 22 & $F$ & $\begin{array}{r}12.5 \\
6.7 \\
\end{array}$ & $\begin{array}{l}4.5 \\
4.2 \\
\end{array}$ & $\begin{array}{l}5.3 \\
5.3\end{array}$ & $\begin{array}{l}5.0 \\
5.6\end{array}$ & $\begin{array}{l}4.3 \\
3.8\end{array}$ & $\begin{array}{l}7.1 \\
3.6 \\
\end{array}$ & $\begin{array}{l}5.9 \\
5.3 \\
\end{array}$ & $\begin{array}{l}5.0 \\
1.3 \\
\end{array}$ \\
\hline 22 & K.S. & 22 & $M$ & $\begin{array}{r}16.7 \\
5.0 \\
\end{array}$ & $\begin{array}{l}9.1 \\
3.2 \\
\end{array}$ & $\begin{array}{r}12.5 \\
4.0 \\
\end{array}$ & $\begin{array}{r}12.5 \\
3.8 \\
\end{array}$ & $\begin{array}{r}12.5 \\
3.7 \\
\end{array}$ & $\begin{array}{r}14.3 \\
3.8 \\
\end{array}$ & $\begin{array}{r}14.3 \\
3.8 \\
\end{array}$ & $\begin{array}{r}14.3 \\
3.8 \\
\end{array}$ & 55 & K.K. & 25 & $\mathrm{~F}$ & $\begin{array}{r}14.3 \\
5.9 \\
\end{array}$ & $\begin{array}{l}4.0 \\
4.0 \\
\end{array}$ & $\begin{array}{l}.1 \\
3.9 \\
\end{array}$ & $\begin{array}{r}25.0 \\
4.0 \\
\end{array}$ & $\begin{array}{r}14.3 \\
5.6 \\
\end{array}$ & \begin{tabular}{|r|}
33.3 \\
5.6 \\
\end{tabular} & $\begin{array}{r}25.0 \\
6.3 \\
\end{array}$ & $\begin{array}{r}25.0 \\
5.0 \\
\end{array}$ \\
\hline 23 & T.T. & 16 & $M$ & $\begin{array}{l}11.1 \\
14.3 \\
\end{array}$ & $\begin{array}{r}12.5 \\
6.7 \\
\end{array}$ & $\begin{array}{r}14.3 \\
4.3 \\
\end{array}$ & $\begin{array}{r}50.0 \\
8.3 \\
\end{array}$ & $\begin{array}{r}16.5 \\
4.5 \\
\end{array}$ & $\begin{array}{r}14.3 \\
5.3 \\
\end{array}$ & $\begin{array}{r}16.7 \\
5.6 \\
\end{array}$ & \begin{tabular}{|r|}
16.7 \\
5.9 \\
\end{tabular} & 56 & s.o. & 19 & M & $\begin{array}{r}3.2 \\
12.5 \\
\end{array}$ & $\begin{array}{l}3.2 \\
3.9\end{array}$ & $\begin{array}{l}3.1 \\
9.1\end{array}$ & $\begin{array}{l}2.6 \\
9.1\end{array}$ & $\begin{array}{r}3.3 \\
10.0 \\
\end{array}$ & $\begin{array}{r}3.0 \\
11.1 \\
\end{array}$ & $\begin{array}{r}3.6 \\
12.5 \\
\end{array}$ & $\begin{array}{r}3.3 \\
11.1 \\
\end{array}$ \\
\hline 24 & A.M. & 26 & $M$ & $\begin{array}{r}33.3 \\
5.6 \\
\end{array}$ & $\begin{array}{r}10.0 \\
3.7 \\
\end{array}$ & $\begin{array}{r}12.5 \\
8.3 \\
\end{array}$ & $\begin{array}{r}20.0 \\
3.9 \\
\end{array}$ & $\begin{array}{r}20.0 \\
6.3 \\
\end{array}$ & $\begin{array}{r}20.0 \\
5.0 \\
\end{array}$ & $\begin{array}{r}25.0 \\
3.6 \\
\end{array}$ & $\begin{array}{r}12.5 \\
5.3 \\
\end{array}$ & 57 & M.Y. & 19 & M & $\begin{array}{r}33.3 \\
5.9 \\
\end{array}$ & $\begin{array}{l}2.9 \\
3.1\end{array}$ & $\begin{array}{l}7.1 \\
3.0\end{array}$ & $\begin{array}{r}6.7 \\
4.0\end{array}$ & $\begin{array}{r}16.7 \\
4.2\end{array}$ & \begin{tabular}{|r}
33.3 \\
4.6 \\
\end{tabular} & $\begin{array}{r}100.0 \\
5.0\end{array}$ & $\begin{array}{r}100.0 \\
5.3 \\
\end{array}$ \\
\hline 25 & K.M. & 21 & $F$ & $\begin{array}{r}50.0 \\
6.3 \\
\end{array}$ & $\begin{array}{l}6.3 \\
4.6 \\
\end{array}$ & $\begin{array}{r}50.0 \\
6.7 \\
\end{array}$ & $\begin{array}{r}33.3 \\
6.3 \\
\end{array}$ & $\begin{array}{r}100.0 \\
4.4 \\
\end{array}$ & $\begin{array}{r}33.3 \\
7.7 \\
\end{array}$ & $\begin{array}{r}33.3 \\
4.8 \\
\end{array}$ & $\begin{array}{r}20.0 \\
6.3 \\
\end{array}$ & 58 & T.M. & 33 & M & $\begin{array}{l}9.1 \\
4.8 \\
\end{array}$ & $\begin{array}{l}4.6 \\
4.6 \\
\end{array}$ & $\begin{array}{l}9.1 \\
7.7 \\
\end{array}$ & $\begin{array}{l}8.3 \\
8.3 \\
\end{array}$ & $\begin{array}{r}5,6 \\
10.0 \\
\end{array}$ & $\begin{array}{r}4.2 \\
16.7 \\
\end{array}$ & $\begin{array}{r}5.6 \\
10.0 \\
\end{array}$ & $\begin{array}{r}7.7 \\
12.5 \\
\end{array}$ \\
\hline 26 & H.K. & 26 & $\mathrm{~F}$ & $\begin{array}{l}6.7 \\
2.6 \\
\end{array}$ & $\begin{array}{l}3.4 \\
2.5 \\
\end{array}$ & $\begin{array}{r}4.0 \\
2.6 \\
\end{array}$ & $\begin{array}{l}5.3 \\
3.3 \\
\end{array}$ & $\begin{array}{l}3.6 \\
3.7 \\
\end{array}$ & $\begin{array}{l}3.4 \\
3.7 \\
\end{array}$ & $\begin{array}{l}3.2 \\
3.0 \\
\end{array}$ & $\begin{array}{l}4.0 \\
3.8 \\
\end{array}$ & 59 & M. $\mathrm{T}$ & 19 & $\mathrm{~F}$ & $\begin{array}{l}6.7 \\
9.1 \\
\end{array}$ & $\begin{array}{l}3.7 \\
6.3 \\
\end{array}$ & $\begin{array}{l}5.0 \\
7.1\end{array}$ & $\begin{array}{l}7.7 \\
7.1 \\
\end{array}$ & $\begin{array}{r}9.1 \\
10.0\end{array}$ & $\begin{array}{r}5.0 \\
10.0\end{array}$ & $\begin{array}{r}4.8 \\
14.3 \\
\end{array}$ & $\begin{array}{r}5.9 \\
12.5 \\
\end{array}$ \\
\hline 27 & М.K. & 19 & $\mathrm{~F}$ & $\begin{array}{r}9.1 \\
33.3 \\
\end{array}$ & $\begin{array}{l}12.5 \\
20.0 \\
\end{array}$ & $\begin{array}{l}11.1 \\
20.0 \\
\end{array}$ & $\begin{array}{r}16.7 \\
109.0 \\
\end{array}$ & \begin{tabular}{|r|}
33.3 \\
100.0 \\
\end{tabular} & $\begin{array}{r}33.3 \\
100.0 \\
\end{array}$ & $\begin{array}{l}100.01 \\
100.09\end{array}$ & $\begin{array}{l}100.01 \\
100.01\end{array}$ & 60 & M. 0 . & 26 & $M$ & $\begin{array}{r}33.3 \\
5.6\end{array}$ & $\begin{array}{r}10.0 \\
3.7\end{array}$ & $\begin{array}{r}12.5 \\
8.3\end{array}$ & $\begin{array}{r}20.0 \\
3.9\end{array}$ & $\begin{array}{r}20.0 \\
6.3\end{array}$ & $\begin{array}{r}20.0 \\
5.0\end{array}$ & $\begin{array}{r}25.0 \\
3.6 \\
\end{array}$ & $\begin{array}{r}12.5 \\
5.3 \\
\end{array}$ \\
\hline 28 & I.K. & 20 & $E$ & $\begin{array}{r}5.9 \\
33.3 \\
\end{array}$ & $\begin{array}{l}4.3 \\
4.5 \\
\end{array}$ & $\begin{array}{r}4.3 \\
10.0 \\
\end{array}$ & $\begin{array}{r}4.0 \\
50.0 \\
\end{array}$ & $\begin{array}{r}5.6 \\
100.0 \\
\end{array}$ & $\begin{array}{r}6.7 \\
100.0 \\
\end{array}$ & $\begin{array}{r}7.7 \\
100.0 \\
\end{array}$ & $\begin{array}{r}10.0 \\
100.0 \\
\end{array}$ & 61 & H.O. & 25 & $M$ & $\begin{array}{l}4.6 \\
3.6 \\
\end{array}$ & $\begin{array}{l}3.6 \\
3.1 \\
\end{array}$ & $\begin{array}{l}3.3 \\
4.6 \\
\end{array}$ & $\begin{array}{l}.8 \\
3.7 \\
\end{array}$ & $\begin{array}{l}3.7 \\
3.7 \\
\end{array}$ & $\begin{array}{l}4.2 \\
4.6 \\
\end{array}$ & $\begin{array}{l}4.0 \\
5.6 \\
\end{array}$ & $\begin{array}{l}5.6 \\
4.1 \\
\end{array}$ \\
\hline 29 & K.E. & 36 & F & $\begin{array}{r}5.9 \\
12.5 \\
\end{array}$ & $\begin{array}{l}4.3 \\
7.7 \\
\end{array}$ & $\begin{array}{l}7.1 \\
8.3 \\
\end{array}$ & $\begin{array}{r}7.7 \\
10.0 \\
\end{array}$ & $\begin{array}{l}7.7 \\
6.3 \\
\end{array}$ & $\begin{array}{l}5.6 \\
9.1 \\
\end{array}$ & $\begin{array}{r}5.6 \\
10.0 \\
\end{array}$ & $\begin{array}{r}5.9 \\
10.0 \\
\end{array}$ & 62 & H.F. & 25 & $\mathrm{M}$ & $\begin{array}{l}5.6 \\
6.7 \\
\end{array}$ & $\begin{array}{l}4.2 \\
4.2 \\
\end{array}$ & $\begin{array}{r}5.6 \\
14.3 \\
\end{array}$ & $\begin{array}{r}5.6 \\
12.5 \\
\end{array}$ & $\begin{array}{r}5.3 \\
14.3 \\
\end{array}$ & $\begin{array}{r}6.7 \\
16.7 \\
\end{array}$ & $\begin{array}{r}5.6 \\
10.0 \\
\end{array}$ & $\begin{array}{r}7.7 \\
12.5 \\
\end{array}$ \\
\hline 30 & M.K. & 20 & $F$ & $\begin{array}{r}6.7 \\
11.1 \\
\end{array}$ & $\begin{array}{l}6.3 \\
5.0 \\
\end{array}$ & $\begin{array}{l}6.3 \\
5.0 \\
\end{array}$ & $\begin{array}{l}9.1 \\
5.9 \\
\end{array}$ & $\begin{array}{r}10.0 \\
5.9 \\
\end{array}$ & $\begin{array}{l}9.1 \\
5.6 \\
\end{array}$ & $\begin{array}{l}9.1 \\
5.8 \\
\end{array}$ & $\begin{array}{l}9.1 \\
4.2 \\
\end{array}$ & 63 & $\AA .0$ & 21 & F & $\begin{array}{l}8.3 \\
6.3 \\
\end{array}$ & $\begin{array}{l}4.5 \\
5.3\end{array}$ & $\begin{array}{l}5.9 \\
4.0 \\
\end{array}$ & $\begin{array}{l}7.7 \\
7.1 \\
\end{array}$ & $\begin{array}{l}8.3 \\
7.7 \\
\end{array}$ & $\begin{array}{r}8.3 \\
20.0 \\
\end{array}$ & $\begin{array}{r}5.9 \\
22.5 \\
\end{array}$ & $\begin{array}{r}14.3 \\
8.3 \\
\end{array}$ \\
\hline 31 & R.o. & 37 & F & $\begin{array}{l}7.1 \\
4.6 \\
\end{array}$ & $\begin{array}{l}4.8 \\
3.6 \\
\end{array}$ & $\begin{array}{r}5.3 \\
4.0 \\
\end{array}$ & $\begin{array}{r}4.0 \\
4.4 \\
\end{array}$ & $\begin{array}{l}5.3 \\
3.9 \\
\end{array}$ & $\begin{array}{r}4.8 \\
4.8 \\
\end{array}$ & $\begin{array}{r}1.6 \\
5.6 \\
\end{array}$ & $\begin{array}{l}5.3 \\
5.0 \\
\end{array}$ & 64 & S.K. & 17 & $\mathrm{~F}$ & $\begin{array}{l}5.0 \\
1.6 \\
\end{array}$ & $\begin{array}{l}3.3 \\
3.6 \\
\end{array}$ & $\begin{array}{l}6.3 \\
3.0 \\
\end{array}$ & $\begin{array}{r}12.5 \\
3.9 \\
\end{array}$ & $\begin{array}{r}12.5 \\
4.0 \\
\end{array}$ & $\begin{array}{r}10.0 \\
3.6 \\
\end{array}$ & $\begin{array}{r}12.5 \\
4.2 \\
\end{array}$ & \begin{tabular}{|r|}
10.0 \\
4.5 \\
\end{tabular} \\
\hline 32 & H.T. & 35 & $\mathrm{~F}$ & $\begin{array}{l}6.7 \\
3.8 \\
\end{array}$ & $\begin{array}{l}4.5 \\
3.8 \\
\end{array}$ & $\begin{array}{l}5.0 \\
3.6 \\
\end{array}$ & $\begin{array}{l}5.6 \\
5.0 \\
\end{array}$ & $\begin{array}{l}5.9 \\
5.0\end{array}$ & $\begin{array}{l}6.7 \\
8.3 \\
\end{array}$ & $\begin{array}{r}6.7 \\
10.0 \\
\end{array}$ & $\begin{array}{l}6.7 \\
9.1 \\
\end{array}$ & 65 & H.H. & 24 & $F$ & $\begin{array}{l}25.0 \\
16.7\end{array}$ & $\begin{array}{l}4.0 \\
7.1\end{array}$ & $\begin{array}{r}16.7 \\
7.1 \\
\end{array}$ & $\begin{array}{l}11.1 \\
12.5 \\
\end{array}$ & $\begin{array}{l}16.7 \\
16.7 \\
\end{array}$ & $\begin{array}{r}100.0 \\
20.0 \\
\end{array}$ & $\begin{array}{l}33.3 \\
33.3 \\
\end{array}$ & \begin{tabular}{|l|}
33.3 \\
50.0 \\
\end{tabular} \\
\hline 33 & S.S. & 23 & $M$ & $\begin{array}{r}5.9 \\
14.3 \\
\end{array}$ & $\begin{array}{l}4.0 \\
5.9 \\
\end{array}$ & $\begin{array}{l}7.1 \\
6.7 \\
\end{array}$ & $\begin{array}{r}11.1 \\
9.1 \\
\end{array}$ & $\begin{array}{l}7.1 \\
8.3 \\
\end{array}$ & $\begin{array}{r}14.3 \\
9.1 \\
\end{array}$ & $\begin{array}{r}13.3 \\
8.3 \\
\end{array}$ & $\begin{array}{l}9.1 \\
9.1 \\
\end{array}$ & 66 & N.N. & 25 & M & $\begin{array}{l}3.0 \\
3.2 \\
\end{array}$ & \begin{tabular}{|l|}
2.0 \\
3.3 \\
\end{tabular} & $\begin{array}{r}2.2 \\
14.3 \\
\end{array}$ & $\begin{array}{r}1.9 \\
25.0 \\
\end{array}$ & $\begin{array}{r}2.2 \\
12.5 \\
\end{array}$ & $\begin{array}{r}2.4 \\
33.3 \\
\end{array}$ & $\begin{array}{c}2.7 \\
33.3 \\
\end{array}$ & $\begin{array}{r}3.5 \\
100.0 \\
\end{array}$ \\
\hline
\end{tabular}




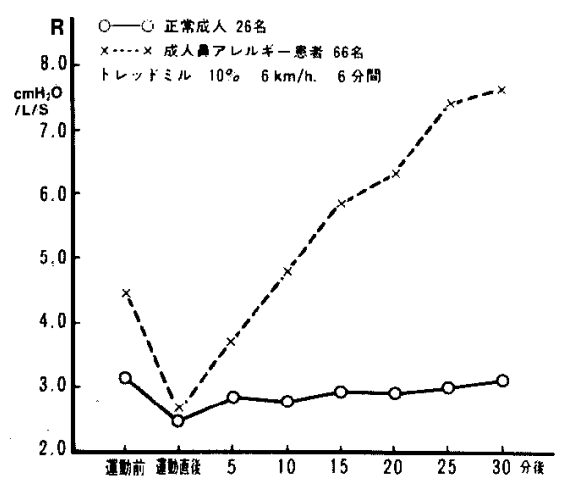

a)

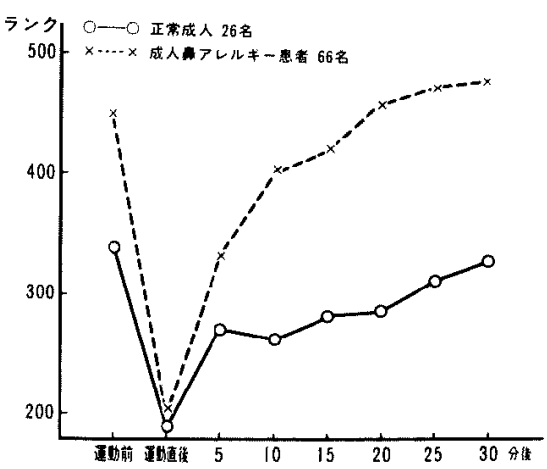

b )

図 2 運動負荷による全鼻腔抵抗の変化

a) 鼻腔抵抗值

b ）鼻腔抵抗值の順位変換

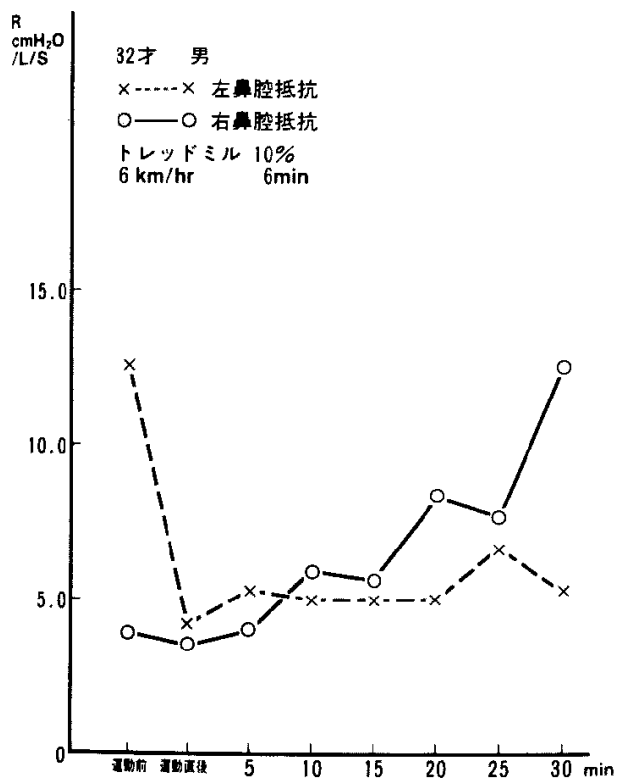

図 3 正常成人の運動負荷前後の片側㐭腔抵 抗の変化

形判別分析（重回帰分析）を行った。線形判別分析は，

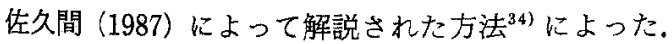
その結果, スコアは,

$\mathrm{SCORE}=0.0011 \mathrm{~A}+0.0082 \mathrm{~B}-0.0080 \mathrm{C}+1.1344$

\section{$A=$ 安静時の左右差 \\ $\mathrm{B}=$ 運動直後の左右差 \\ $\mathrm{C}=$ 安静時の全鼻腔抵抗值}

の式のようになり，そのスコアによる累積分布曲線は， 図 $4 \mathrm{c}$ のようになり，2 群の交点は, $\mathrm{SCORE}=1.26$ と
なった。

次に，運動後の片側鼻腔抵抗の変化をみると成人鼻 アレルギ一患者のうち，15例，23\%に，運動後，片側 鼻腔抵抗值が, 著しく上昇した $\left(100 \mathrm{cmH}_{2} \mathrm{O} / \mathrm{L} / \mathrm{S}\right.$ 以上) 症例があった。このような現象は, 正常成人には 1 例 も認められなかった。また，鼻腔形態異常を伴った鼻 アレルギー患者は 6 名で,伴わなかった者との間には, 有意の差はみられなかった。

また，運動後の30分の観察中に左右の鼻腔抵抗値の 大小が逆転した例，すなわち Nasal Cycle の逆転が認 められたものが, 正常成人 26 例中 11 例 $(42 \%)$ ，成人鼻 アレルギー患者66例中21例 $(32 \%)$ あった。

（3）運動負荷の鼻腔抵抗および下気道におよほす影 響 (小児)

正常児 5 名, 気管支喘息児50名，小児鼻アレルギー 患者15名に，トレッドミルにて運動負荷を行った結果 は次の通りである，正常児扔よび，小児悬アレルギー 患者には，運動後に，FEV 1.0 が前の值に $15 \%$ 以上の低 下を示した症例は，一例もなかった。一方，気管支喘 息児については，運動直後から30分後までの間に， $\mathrm{FEV}_{1.0}$ が, 運動前の值の15\%以上の低下を示した症例 が，32例 $(64 \%)$ あった。 その中で，FEV 後に最も低下した症例が，23例，10分後が 7 例，20分 後が 2 例であった，最も著しい例においては渾動前の 值の63\%の低下をみた。

次に，正常児，小児鼻アレルギー患者，気管支喘息 照の運動負荷による礐腔抵抗の変化では，成人と同様 に，運動により，直後では鼻腔抵抗の減少がみられ， 正常児, 気管支喘息児，小悲鼻アレルギー患者の全鼻 


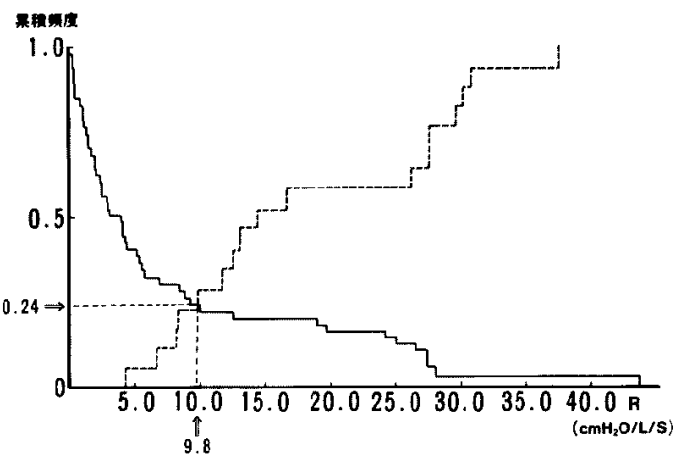

a)

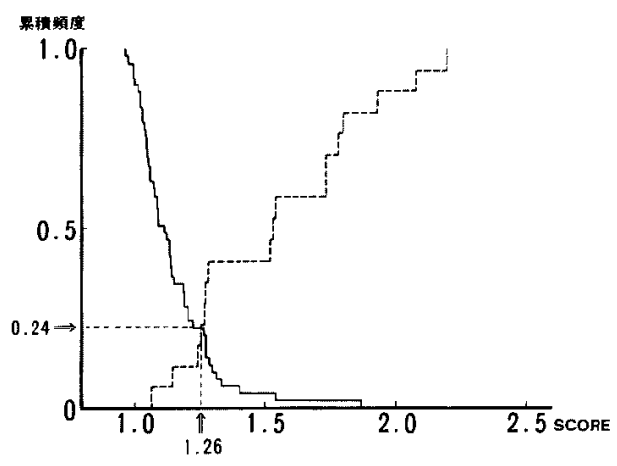

c)

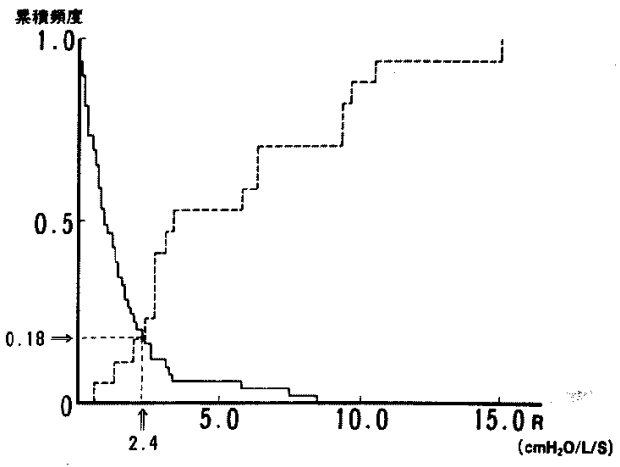

b)

図 4 鼻腔骨格形態異常を伴った鼻アレルギー患者と伴わない患者における鼻 腔抵抗値の左右差の比較

a) 安静時 (実線：鼻腔骨格形態異常のない症例，破線：ある症例)

b) 運動直後

c）安静時と運動直後の鼻腔抵抗值の左右差をスコア化した場合 $\mathrm{SCORE}=0.0011 \mathrm{~A}+0.0082 \mathrm{~B}-0.0080 \mathrm{C}+1.1344$

$$
\begin{aligned}
& A=\text { 安静時の左右差 } \\
& B=\text { 運動直後の左右差 } \\
& C=\text { 安静時の全鼻腔抵抗值 }
\end{aligned}
$$

表 5 気管支喘息児50名に扔ける運動による $\mathrm{EIA} と \mathrm{EINO}$ との相関

\begin{tabular}{|c|c|c|c|}
\hline & EIA ( +$)$ & EIA (-) & 計 \\
\hline EINO (t) & 12 例 & 7例 & 19 例 \\
\hline EINO (-) & 20 例 & 11 例 & 31 例 \\
\hline 計 & 32 例 & 18 例 & 50 例 \\
\hline
\end{tabular}

*EIA (+) : 運動後の1秒量(FEV 以上の低下を示したもの

EINO(+)：運動後, 片側腔抵抗值が $100 \mathrm{cmH}_{2} \mathrm{O} / \mathrm{L} / \mathrm{S}$ 以上になるもの

( $x^{2}$ test : N.S.)

腔抵抗值は, $3.3 \pm 0.8 \mathrm{cmH}_{2} \mathrm{O} / \mathrm{L} / \mathrm{S}, 3.2 \pm 0.8,3.0 \pm 1.5$ と ほぼ等しい值を示した．続いて，5分後からは，再び
鼻腔抵抗は上昇傾向を示し，気管支喘息児，小児鼻ア レルギー患者の中には，15～20分後から運動前の鼻嘧 抵抗值をはるかに越える症例があり，その中で，運動 後に, 片側鼻腔抵抗值が $100 \mathrm{cmH}_{2} \mathrm{O} / \mathrm{L} / \mathrm{S}$ を越えた症 例が，小児鼻アレルギー患者では，15例中 6 例(40\%)， 気管支喘息児では，50例中18例（36\%）にみられた。 しかしながら，この現象は正常児には全くみられなか った。次に，気管支喘息児において， $\mathrm{FEV}_{1.0}$ が15\%以 上の低下がみられた症例と，運動後，片側鼻腔抵抗が $100 \mathrm{cmH}_{2} \mathrm{O} / \mathrm{L} / \mathrm{S}$ を越えた症例の相関をみてみると、表 5 になり，この 2 つの現象における相関はみられなか つた. 


\section{5. 考察}

(1) 鼻腔抵抗測定法

鼻腔生理学において, 鼻腔の通気性に関する研究は, 永年のテーマとして，諸家により研究されてきた。 ま ず，兽腔の通気性の表現を，はじめて記載したのは， Zwaardemaker $(1896)^{35)}$ だと言われている，間接的鼻 腔通気度観察法としては Glatzel (1901) ${ }^{36)}$ の金属板が よく知られている。これは，呼気斑の大きさおよび嘬 りの消失時間を測定する方法である，その後も鼻控の

、通気性を観察するいろいろな工夫がなされてきた $か^{33137 / 38) 399}$ ，直接鼻腔内の流速および圧差を測定する 方法が一般的になり，本邦でも鼻腔通気度の測定法の 標準化が検討されている(0141).この方法は, Pneumotachograph 用いて, 呼吸流速を測定し, 同時に前鼻孔 と後鼻孔の圧差を測定し, その圧差と流速から気道抵 抗を算出する方法であり，これには，Anterior 法 (前 方䅎導法) と Posterior 法 (後方誘導法) がある ${ }^{131}$. こ

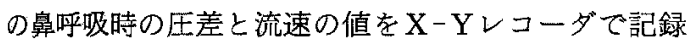
させてみると直線にはならず， $\mathrm{S}$ 字状の曲線になる。

これを圧一流速曲線 ${ }^{42)}$ まは, 鼻腔通気度曲線とい $\zeta^{43)}$. 鼻腔の通気性の表現法は, 鼻腔抵抗, 鼻腔通気 度 ${ }^{44}$ ，あるいは，鼻腔有効断面積 ${ }^{45) 46447) な と ゙ か ゙ あ る か ゙ ， ~}$ 現在は鼻腔を通過する空気を, 電気にたとえ, 鼻腔抵 抗 $\mathrm{R}=\mathrm{P}$ (圧差) $/ \dot{\mathrm{V}}$ (流速) と定義し，X-Yレコーダ により記録された圧差および流速から，鼻空抵抗值を 算出する方法が広く用いられている。しかしながら， この鼻腔通気度曲線から求める $\mathrm{P} / \mathrm{V}$ は, 一定の值には ならず,各測定点により, 異なった值をとる ${ }^{487}$.これは, 鼻内の気流が，層流と乱流とによって成り立っている

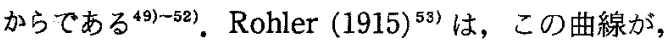
$\mathrm{P}=\mathrm{k}_{1} \dot{\mathrm{V}}+\mathrm{k}_{2} \dot{\mathrm{V}}^{2}$ に近似てきるとし, $\mathrm{k}_{1}$ を層流係数, $\mathrm{k}_{\mathrm{z}}$ を乱流係数とした。従って, $\dot{\mathrm{V}}=0$ に近いほど層流 係数の影響が強く，反対にVが大きくなればなるほど 乱流係数の影響が非常に強くなる。従って，鼻腔抵抗 值の算出する基準点には，層流成分と乱流成分の影響 を十分加味できる点にとるのが理想的である．日本人 の鼻腔通気度曲線の到達率から考えると ${ }^{54)}$, 日本人で は，基準点としては， $\mathrm{P}=1.0 \mathrm{cmH}_{2} \mathrm{O}$ あるいは $\dot{\mathrm{V}}=$ $0.25 \mathrm{~L} / \mathrm{S}$ が良いと考えられる。しかしながら Anterior 法を用いた場合, 片側の鼻腔抵抗值から, 全鼻腔抵抗 值を算出しなければならず，この算出には

$1 /$ 全鼻腔抵抗 $=1 /$ 右鼻腔抵抗 +1 /左鼻腔抵抗 を用いるのが一般的である。この式が，撖密にいって 正しく成り立つのは，Pを一定とした時である，すな

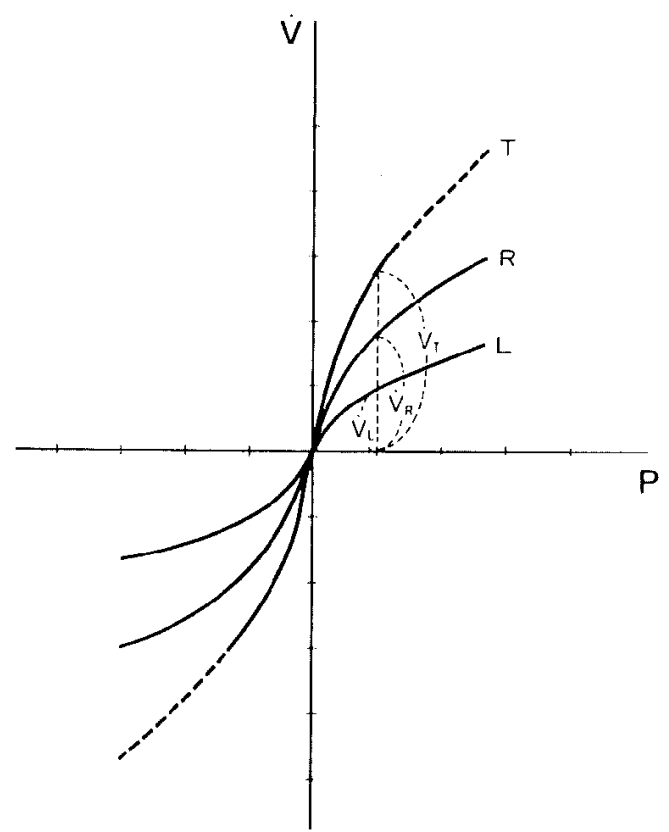

図 5 全鼻腔圧一流速曲線の求め方

$\mathrm{T}$ : 全鼻腔圧一流速曲線 $\mathrm{V}_{\mathrm{T}}$ : 全鼻腔の流速

$\mathrm{R}$ : 右鼻腔圧一流速曲線 $\mathrm{V}_{\mathrm{R}}$ : 右鼻腔の流通

$\mathrm{L}$ ：左鼻腔圧一流速曲線 $\mathrm{V}_{\mathrm{L}}$ : 左鼻腔の流速

(圧一定)

表 6 鼻空抵抗に影響を与える因子
（1）粘膜性因子
- Nasal Cycle
- 姿勢 (Posture)
- 呼吸様式

$$
\begin{aligned}
& \text { 息こらえ (Breath holding) } \\
& \text { 再呼吸 (Rebreathing) } \\
& \text { 過換気状態 (Hyperventilation) }
\end{aligned}
$$
・運動
・温度, 湿度
（2）構造性因子

わち，生理的には，両側鼻腔で呼吸した場合，左の圧 差も右の圧差も等しい. そのため, $\operatorname{Bachmann}(1976)^{55)}$ は，右側と左側鼻腔の圧差（P）を一定にした時の， 各々の流速 $\left(\dot{\mathrm{V} r} \mathrm{r} \cdot \dot{\mathrm{V}}_{1}\right)$ を加算した $\dot{\mathrm{V}}_{\mathrm{t}}=\dot{\mathrm{V}}_{\mathrm{r}}+\dot{\mathrm{V}}_{1}$ が，そ の圧差（P）に扔る全鼻腔の流速になると述べてい る.そこで, 右の压一流速曲線と左の圧一流速曲線を， 圧差（P）を基準とし，加算することにより，新たな 全鼻腔の圧一流速曲線を描くことができる(図 5 ). と ころが，片側鼻腔で鼻呼吸する時と，全鼻空で鼻呼吸 
する時では, 1 回の呼吸は, 片側鼻呼吸で必要な圧差 を必要としないため, 実際の圧一流速は, この方法で 求めた圧一流速曲線の一部になる ${ }^{54)}$. また, この曲線 は, Posterior 法で測定した，圧一流速曲線に近似す る. 従って, 今回の鼻腔抵抗測定にあたっては, 生理 的な意味と, 計算式で求められることから, $\mathrm{P}=$ $1.0 \mathrm{cmH}_{2} \mathrm{O} / \mathrm{L} / \mathrm{S}$ での鼻腔抵抗值を算出した。

一方, 圧一流速曲線は, 呼気および吸気時の, 鼻腔 抵抗を算出できるが，それらの值は，必ずしも一致し な(222)48(56)57). 鼻の機能の一つに, 呼気性ブレーキがあ り, 呼吸の際の鼻腔抵抗は, 呼気時の肺の収縮を円滑 にするため, 喉頭, とくに声帯とともに，鼻が重要な 働きをしている ${ }^{58)}$.また，呼吸機能検查においては Peak Flow 值, $V_{50}, V_{25}$, など, 呼出機能を問題とし ている場合が多い.したがって，今回の鼻腔抵抗の測 定に対しては，呼気時の抵抗值を採用した。

(2) 鼻腔抵抗の生理的変動

鼻腔の通気性に影響を与える因子としては，粘膜性 因子と，構造性因子とに大別することができる，構造 性因子とは, 鼻中隔や甲介骨などの骨格構造に起因す るもので, 日常生活においては, 通気性に大きな変化 は与えない, 一方, 鼻中隔粘膜や甲介粘膜は, 安静状 態にあっても, 常に一定の状態にあるわけではなく, 自動的にあるいは生体周囲環境の影響を受け, 変動す る.これらの変動をひきおこす因子を, 粘膜性因子と いう．鼻粘膜に変動を与える因子としては表 6 にあげ たものが考えられる.したがって，今回の鼻腔抵抗の 測定においても，これらの因子の影響を最小限にする ように，条件設定を行った。しかしながら，そのなか で Nasal Cycle は, 今回の測定においても無視できな い因子と考えられる.

(O) Nasal Cycle

左右の鼻粘膜は, 安静にしていても, 常に一定の状 態には保たれてはいない. 生体のバイオリズムの1つ に, Nasal Cycle が存在する.これは, 左右の鼻腔の 粘膜が, 交代性に, 腫脹, 収縮をくりかえす現象であ る.例えば，右鼻腔抵抗が増大しても，左鼻腔抵抗は 低下するので，その結果，全鼻腔における抵抗はあま り大きな変動はない. Nasal Cycle は, Eccles(1981) ${ }^{59)}$ によると，中枢性，おそらく視床下部によって制御さ れている可能性が強い. また, この現象は正常人の72 \%に認められ ${ }^{10)}$, 性差はなく, 平均 2.6 時間の周期であ ると言われ，高齢者程，延びる傾向にある，鼻アレル ギーや血管運動性鼻炎の患者では，この Nasal Cycle

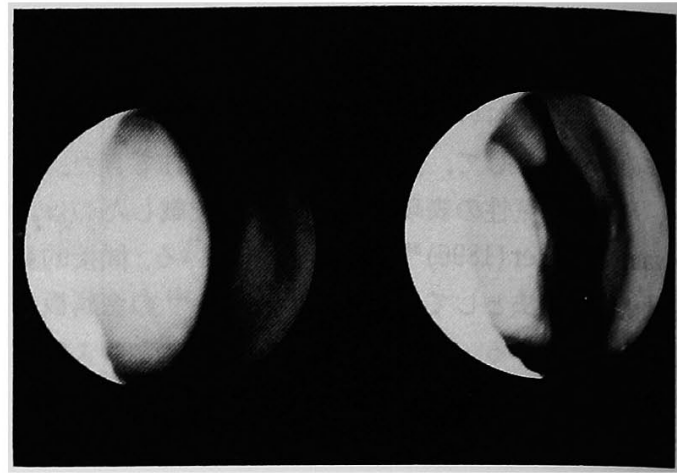

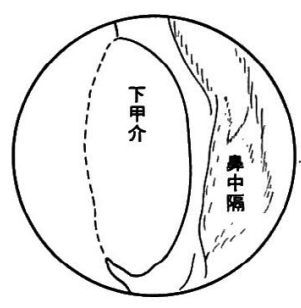

運動 前

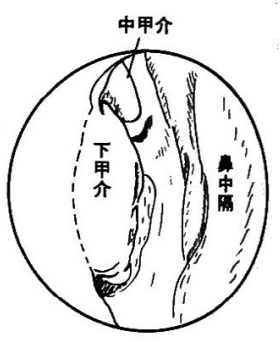

運動直後
図 6 正常成人の運動前後の鼻粘膜

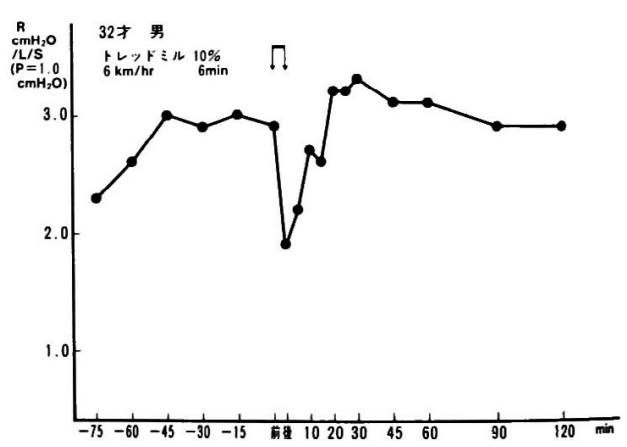

図 7 正常成人における運動負荷による 全鼻抵抗の変化

は誇張された形で現われ，交代性鼻閉として，自覚さ れる ${ }^{12)}$. 今回の測定においては, 運動後に左右の鼻腔抵 抗値の逆転が認められたのは，正常成人において，26 例中 11 例 (42\%)，成人鼻アレルギー患者において66例 中21例(32\%)であった.これは, 運動が, Nasal Cycle をも変動させる強い刺激であることを示唆するもので ある。

(3) 運動と鼻腔抵抗

運動も，鼻粘膜に変動を与える因子として重要であ る(表 6)。一般には運動により，鼻腔抵抗值は小さく なり,この状態は $3 \sim 4$ 分続くと言われる ${ }^{29)}$. しかしな 
がら、これまでの報告では, 主として運動直後の鼻控 抵抗の変化のみに注目し, 運動後の鼻腔抵抗の変化, 特に畕アレルギー患者における鼻腔抵抗の変化につい ては，あまり関心が払われていなかった，下気道に扔 いては, 運動誘発喘息という現象が, 存在し, 運動直 後だけではなく, その後の経過により, 気道の粘膜に 変化を生ずる可能性が示唆される。したがって，鼻粘 膜においても運動後の変化について追跡し，倹討する 必要があると思われた。 そこで, 今回は, 鼻腔通気度 計により，客観的に，より正確に鼻釷抵抗を測定する ことにより，鼻粘膜の運動による変化について，検討 を行った。

(a) 正常者における運動と鼻空抵抗

正常者の運動前後の鼻腔内をみると, 運動によって 下甲介が収縮し，総鼻道が開く（図 6)。したがって， 鼻㕵抵抗測定に際しては，検查前に，一定の時間，安 静を保たせる必要がある．被験者に日常の行動をとら せた後, 安静をとらせた場合の鼻腔抵抗をみてみると， 30分後に，抵抗が安定してくるのが分かる(図 7 )。従 って，鼻腔抵抗の測定にあたっては，最低30分以上の 安静が必要であり，これは，国際標準化委員会の基準 (Committee report on stndardization of rhinomanometry, 1983) ${ }^{601}$ とも一致する.

運動による鼻腔抵抗值の減少は, 生理的変動の中で も，特に䫓著なものである。これまでの報告では，運 動負荷後, 約50\%前後の鼻腔抵抗の減少があると言わ れている ${ }^{29)}$.また, 運動の強さによっても，鼻腔抵抗の 減少は異なる ${ }^{299}$. 今回のトレッドミルによる $10 \%$, 時速 $6 \mathrm{~km} 6$ 分間の運動負荷は, 小児の運動誘発喘息の運動 負荷検査の基準に従って行った ${ }^{61)}$.この負荷基準は,小

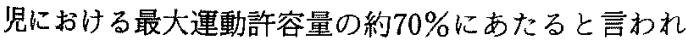
ている、次に，運動の持続時間の差による，鼻腔抵抗 值の減少を比べるため，運動負荷量を一定にして（10 $\%$, 時速 $6 \mathrm{~km}, 6$ 分問), 負荷時間を 2 分， 4 分， 6 分 と変えて，測定してみた結果からは，この程度の負荷 時間の変化では，滅少の割合は，あまり変化しないこ とが明らかになった．これは，Forsyth $(1983)^{29)}$ の結 果と，一致した。

(b) 鼻腔形態と運動の関係

運動直後の片側鼻腔抵抗の值は, Nasal Cycle の収 縮側では，運動前後におけるその変化は少ないが，腫 脹側においては，その変化は大きい。その結果，運動 直後においては, 左右の鼻腔抵抗の差が，安静時に比 較すると，小さくなる、これは，ある一定の運動負荷
を与えると，鼻粘膜の血管の容積に変化を与え，左右 鼻粘膜の容積が，Maximumに近い状態まで収縮する ためと考える，従って，正常成人での運動による左右 差 $1.0 \pm 0.7 \mathrm{cmH}_{2} \mathrm{O} / \mathrm{L} / \mathrm{S}$ は，すなわち，正常人の鼻腔形 態の左右差の範囲内を示す一つの指標であろうと考え る.そこで，この正常成人の鼻腔形態の左右差を越え た場合に鼻腔形態異常が存在すると考えた。事実，鼻 アレルギー患者では，運動直後においても，鼻腔抵抗 值に左右差が存在していた。これは，鼻アレルギ一患 者が，鼻粘膜病変だけでなく，鼻中隔彎曲などの鼻腔 骨格形態異常を伴っていることが多いためと考えられ る. 66名の成人鼻アレルギー患者の中で，鼻腔骨格形 態異常を伴った群と伴わない群とに分けて,それぞれ， 安静時と運動負荷直後の鼻腔抵抗値の左右差を比較し てみた。この二群は，正規性がとほしいため，累積分 布曲線を作ってみた．安静時に扔いては，その二群の 交点（すなわち，false positive と false negative の頻 度が等しくなる点) は, $9.8 \mathrm{cmH}_{2} \mathrm{O} / \mathrm{L} / \mathrm{S}$ であり, false positive, false negative $の$ 頻度（誤診率）は24\%であ った。一方, 運動直後では, $2.4 \mathrm{cmH}_{2} \mathrm{O} / \mathrm{L} / \mathrm{S}, 18 \%$ とな った。この結果は，鼻腔骨格形態異常を鼻腔抵抗値汃 ら, 診断する場合, 安静時より運動直後の鼻腔抵抗値 の左右差の方が，参考になることを意味する，そこで， さらに，運動前後の鼻腔抵抗值から，線形判別分析を 行い，スコア化による判別を試みたがあまり有効では なかった。いずれにせよ，今回の結果は，鼻腔抵抗值 からも，鼻鏡検査，X-P検査だけではなく鼻中隔彎曲 症などの鼻腔形態異常を客観的に評価することが可能 であることを示唆している，つまり，運動負荷は，運 動直後の鼻腔抵抗值の左右差により，運動前の左右差 が, 粘膜性のものか, 鼻腔形態異常などの, 構造性の ものかが推測できる，さらに，正常成人に扔ける鼻腔 抵抗值の左右差の $95 \%$ 信頼限界の值（平均値士2SD）

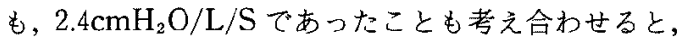
運動直後の左右の鼻腔抵抗值の差が $2.4 \mathrm{cmH}_{2} \mathrm{O} / \mathrm{L} / \mathrm{S}$ 以上の值となる場合, 鼻腔形態異常の存在が強く示唆 される.

(C) 鼻アレルギーと運動

鼻アレルギー患者は, 正常者に比べて, 運動により, ダイナミックな鼻空抵抗の変化がみられる。成人鼻ア レルギー患者66名と正常成人 26 名の全鼻腔抵抗值の変 化をみてみると，安静時には鼻アレルギー患者の抵抗 值は，正常成人に比べて高い傾向にあるが，運動負荷 を行うと，正常成人も鼻アレルギ一患者も，直後の抵 


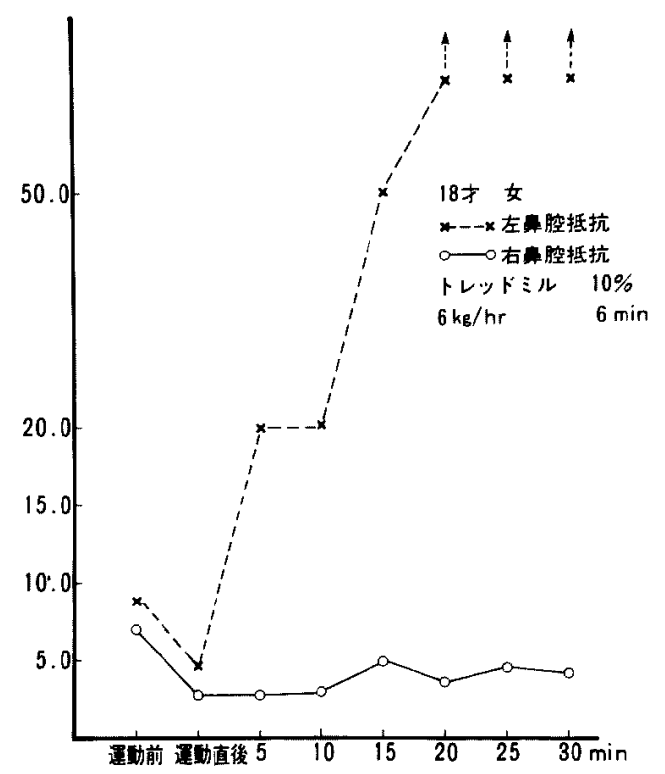

a)

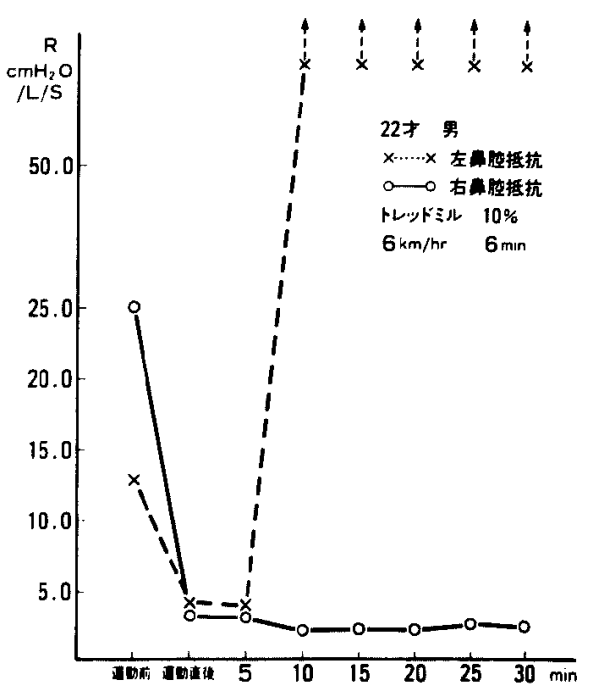

b)

図 8 鼻アレルギー患者の運動負荷による片側鼻腔抵抗の変化

a) 症例 18

b) 症例 7

抗值は,それぞれ, $2.4 \pm 0.7 \mathrm{cmH}_{2} \mathrm{O} / \mathrm{L} / \mathrm{S}, 2.4 \pm$ $0.8 \mathrm{cmH}_{2} \mathrm{O} / \mathrm{L} / \mathrm{S}$ と活湾等しくなる。これは, 鼻アレル ギー患者の鼻閉の原因は，主として粘膜性に腫脹して いることをあらわしている。一方，運動後の鼻腔抵抗 の変化は, 正常者も, 鼻アレルギー患者も, 運動後 15〜20分後で高くなるが，正常者では，安静時より極 端に高くなる傾向は少なく, むしろ安静時の抵抗值を 越えず，ゆっくり元の抵抗值へ戻るのがみられた。一 方, 鼻アレルギー患者では戻り方もダイナミックであ り, 15〜20分後には, 安静時の抵抗值より, はるかに 大きくなっていく傾向がみられた。すなわち，鼻アレ ルギー患者は, 運動前後で, 正常者に比べて, 鼻腔抵 抗の著しい変化がある。これは, 鼻アレルギーの粘膜 には，血流，血管容積あるいは，血管の透過性などに， 正常者とは異なる何らかの特異的な病的反応が存在す るように思われる。

その中で，舅アレルギー患者の一部には，運動を負 荷することによって，15～20分後に，片側鼻腔の抵抗 值が極端に上昇し，完全鼻閉(鼻腔抵抗値 $100 \mathrm{cmH}_{2} \mathrm{O}$ / L/S 以上）を起こす例がある，症例18では，両側鼻腔 抵抗は, 安静時は, それほどは高くないが, 運動によ り, 両側とも抵抗值は極端に小さくなる，ところが,
その後左鼻腔抵抗は 5 分後には, 安静時の抵抗值をは るかに越え，20分後には完全鼻閉となっている.一方, 右鼻腔抵抗は，左鼻挖の完全鼻閉により，安静時の抵 抗值よりむしろ低い值で安定している(図 8 a).また, 症例 7 では, 安静時に高值を示した右鼻腔抵抗任運動 後には, 高くはならず, 反対に, 安静時に低值を示し た左鼻腔が，10分後には，完全鼻閉を示している(図 $8 \mathrm{~b})$.このような完全鼻閉の現象は正常者には全〈み られなかった。また, 安静時における, 腫脹側, 収縮 側との関連性も認められない。症例 7 のような腫脹, 収縮側が逆転する例も，運動が, Nasal Cycleを, 変 化させる程の刺激となりうることを意味する。従って, このような完全鼻閉の現象は, 単なる鼻粘膜局所の問 題ではなく，中枢を介した反心である可能性を示唆し ている.また，この現象と鼻腔骨格形態異常の有無と に関しては，有意差はみられなかった。これは，骨格 構造とこの現象の間には，関連性がないことが示唆さ れるものである。運動によってもたらせる鼻閉の現象 を, 運動誘発鼻閉 (Exercise Induced Nasal Obstruction, EINO) と称し, 『安静時の鼻腔抵抗值が両側とも $35 \mathrm{cmH}_{2} \mathrm{O} / \mathrm{L} / \mathrm{S}$ 以下であり, 運動直後, 片側(どちらか 一側) の鼻腔抵抗值が $100 \mathrm{cmH}_{2} \mathrm{O} / \mathrm{L} / \mathrm{S}$ 以上になる現 
象】と定義し，研究の一部はすでに報告した ${ }^{62)}$.スポー ッマンと鼻アレルギーについては，Katz (1984) ${ }^{631}$ が, 2 人の陸上ランナーが，運動により鼻腔抵抗が上昇し たことを，報告している。ささに，Widdicombe とそ の共同研究者ら $(1985)^{64)}$ も全鼻腔抵抗を別の方法に より測定し，運動後の鼻腔抵抗が上昇するという現象 を指摘しており，rebound として報告している。一方， 運動の下気道に及ぼす影響としては，運動誘発喘息 (EIA)が知られている．EIAは，特に小児の気管支喘 息患者に起こりやすく, 運動後 $5-10$ 分後に喘息発作 を生ずる，その機序としては，様々な機序が考えられ ている，その中で, 気道の Coolingによって EIA がひ きおこされるという考え方が最も一般的である ${ }^{65)}$. 今 回，気管支喘息児50名に運動負荷を与えたところ，64 \%に EIA を生じ，上気道の変化として $38 \%$ EINO を生じた.しかしながら, EINO とEIA の発現には， 明確な相関はみられなかった。さらに，気管支喘息の 症状のない小照鼻アレルギー患者でも15例中 6 例，40 \%にEINOがみられた。 また，成人鼻アレルギー患者 では, 23\%に EINOが認められた。つまり EINOは， 鼻アレルギーにみられる一つの特有な病態現象である と思われる.興味深いことに, EIA とEINOでは負荷 後の発現時間に，5〜10分程度のズレがある。このよ うな時間的ズレがなぜ生ずるかは明らかではないが， EIA, EINO が必ずしも同一の神経伝達物質や，オータ コイドによって，ひき起こされるとは限らない可能性 が示唆される. EINOの反応機序は現在のところ不明 な点が多い.しかしながら, 今回の正常者, 鼻アレル ギ一患者の運動負荷に対する研究から，鼻腔抵抗の変 化は，鼻粘膜への血流，血管容積，血管透過性などが 変動するものと考えられ，その変化は，中枢により制 御され，さらに様々な化学伝達物質が関与しているも のと考える。特に鼻アレルギー患者は，乙の刺激反射 系に異常を生じ，その患者の一部には，15〜20分後に， 過敏反応を示して，EINOといわれるような現象が現 われるものと考える。何故，小児と成人にEINOの発 現率に差があるかは，不明であるが，その考え方の一 つとしては，過敏反応の機序として，小児と成人は， 反射系自体の閵值に差があること，第 2 点として，小 児は，もともと，鼻腔の容積が小さくて，そのため， 安静時においても成人に比へてて, 鼻空抵抗が高く，そ れだけ，反応が出やすいことなどが考えられる，

このように，運動により鼻腔抵抗は，大変興味ある 変動を示す.しかし, その生理学的, 病態生理学的意
味付けは，いまだ，十分とはいえない.その変動は， 血流，あるいは，血管容積の変化などによるものであ ると思われるが，それには，交感，副交感神経系，化 学受容器, あるいは, 各種ケミカルメディエータが, どのように関与しているかは，今後の研究に待たれる ところである。

\section{6. ま と}

鼻腔の通気性は様々な条件の下で，変化する，その 通気性に影響を与える因子としては，構造性因子と粘 膜性因子に大別することができる。これらの因子がど のように鼻腔に影響を与えるかを検討するため, 今回， 鼻腔通気度計を用い，鼻腔抵抗を測定した．本法によ り，鼻腔の通気性を客観的に評価することができた。 その中で, 運動負荷を行い, 䔬腔抵抗の変化を測定し たところ以下のような結果が得られた。

（1）正常成人，成人鼻アレルギ一患者，正常児，小 児鼻アレルギー患者, 気管支喘息児に運動負荷（トレ ッドミル $10 \% 6 \mathrm{~km} / \mathrm{h}, 6$ 分間) 行うと, 運動直後には 鼻腔抵抗の減少がみられ, 鼻アレルボー患者は, 正常 者に比べて，著しい鼻腔抵抗の減少がみられた。

(2) 運動直後の鼻腔抵抗值は, 正常者, 鼻アレルギ 一患者も活等しい值となった。

(3) 運動負荷時間を， 2 分，4 分，6 分と変化させ たが, 運動直後の鼻腔抵抗值の減少には, 有意差がみ られなかった。

(4) 正常者の運動直後の片側鼻腔抵抗值の左右差 は, $1.0 \pm 0.7 \mathrm{cmH}_{2} \mathrm{O} / \mathrm{L} / \mathrm{S}$ と安静時の $4.0 \pm 3.5 \mathrm{cmH}_{2} \mathrm{O} /$ L/Sに比べて減少した. しかしながら，鼻腔骨格形態 異常を伴った鼻アレルギー患者は，運動直後も，鼻控 抵抗値の左右差は，大きく，累積分布曲線による分析 からは, $2.4 \mathrm{cmH}_{2} \mathrm{O} / \mathrm{L} / \mathrm{S}$ より大きい值を示した者には 鼻腔形態異常を示す例が多かった(誤診率 $18 \%$ ). 従っ て, 運動負荷は鼻腔骨格形態異常の客観的評価に有用 であると考えられた。

(5) 運動負荷後の全鼻腔抵抗の変化は, 運動後 5 分 後から鼻腔抵抗值の上昇傾向を示した．正常者が安静 時とほほ変わらない鼻腔抵抗值を示すのに対し, 鼻ア レルギー患者では安静時に比べて全鼻腔抵抗值が上昇 する傾向がみられた。

(6) 運動後の片側鼻整抵抗の変化では, 10〜20分後 に極端に片側鼻腔抵抗值の上昇がみられ, $100 \mathrm{cmH}_{2} \mathrm{O} /$ L/S 以上になる例，すなわち運動誘無鼻閉 (EINO)が 成人鼻アレルギー患者では，15例(23\%)，小児鼻アレ 
ルギー患者，6例 $(40 \%) ，$ 気管支喘息児18例（36\%） にみられた。

(7) 気管支喘息児においては運動誘発鼻閉 (EINO) と運動誘発喘息 (EIA) の間には明らかな相関がみられ なかった。

このように，運動負荷は，ダイナミックに鼻粘膜を 腫脹, 収縮させ, 生理的変動を検索するうえで, 非常 に有益な方法であることが明らかになった．運動直後 の片側鼻空抵抗值の左右差からは，畺腔の骨格構造の 異常をある程度のところまで，推測することができ， 例えば，鼻中隔彎曲症の手術適応を，決めるのにも有 効であろうと考えられる。また，運動後の鼻挖抵抗の 戻り方をみていくと，鼻アレルギー患者においては, 気管支喘息患者（特に小児）の，運動誘発喘息（EIA） と似たような現象，すなわち運動誘発鼻閉 (EINO) と いう現象が発現することが確認された.しかしながら， EIA との間には発現時期の差があり, その発現メカ二 ズムは，まだ不明な点が多い，また，小児と成人の発 現率は，小児の方が高い傾向にあった。このように， EINO は鼻アレルギー粘膜の非特異的刺激に対する反 応プロセスを考えるうえで，極めて示唆に富むもので ある.したがって, EINOの発現機序の解明は，鼻腔生 理, 扔よび, 鼻アレルギーの病態生理の研究の上で, 重要であると考えられた。

\section{参考文献}

1）堀江滋: Phototransistorを応用した鼻用光電式 Plethysmograph の試作と, 鼻中隔粘膜の血管反応. 日 耳鼻 64:284-309，1961.

2）加藤秀雄：反射光電式 Plethysmograph による下鼻介 粘膜血行の臨床的研究.日耳鼻 $68: 305-332 ， 1965$.

3）山川薰：下鼻介粘膜の血行動態に関する臨床的研 究. 日耳鼻 $70: 754-785,1967$.

4) Cody DR, Kern EB, Pearson BW : Ears, Nose, and Throat. Year Book Medical Publishers, Chicago, London 1981.

5) Broms P: Rhinomanometry III (Procedures and criteria for distinction between skeletal stenosis and mucosal swelling. Acta Otolaryngol (Stockh) 94 : 361-370, 1982.

6）野村恭也, 飯沼壽孝：耳鼻咽喉科治療ハンドブック.南 山堂, 東京, 1986.

7) Kayser R: Die exacte Messung der Luftdurchgangigkeit der Nase. Arch Laryngol 3: 101-120, 1895.

8) Heetderks DR: Observations on the reaction of normal nasal mucous membrane. Am J Med Sci 174: 231-244, 1927.

9) Stoksted P: The physiologic cycle of the nose under normal and pathologic conditions. Acta Otolaryngol (Stockh). 42: 175-179. 1952.

10) Hasegawa $M$, Kern EB: Human nasal cycle. Mayo Clin Proc 52 : 28-34, 1977.

11) Eccles $R$ : The domestic pig as experimental animal for studies on the nasal cycle. Acta Otolaryngol (Stockh) 86: 464-468, 1978.

12）長谷川諴：Nasal Cycle の研究. 耳鼻 26: 535543,1980 .

13）長谷川誠：nasal cycle. 日耳番 $86 ： 619-622$, 1983.

14) Rundcrantz $\mathrm{H}$ : Posture and congestion of nasa mucosa in allergic rhisitis. Acta Otolaryngol (Stockh) 58: 283-287, 1964.

15) Rundcrantz $\mathrm{H}$ : Postural variations of nasal patency. Acta Otolarygol (Stockh) 68: 435-443, 1969.

16) Hasegawa $M$, Saito $Y$ : Postural variations in nasal resistance and symptomatology in allergic rhisitis. Acta Otolarygol (Stockh) 88: 268-272, 1979.

17) Haight JSJ, Cole $P$ : Reciprocating nasal airflow resistances. Acta Otolarygol (Stockh) 97: 93-98, 1984.

18) Hasegawa M, Kern EB : The effect of breath holding, hyperventilation and exercise on nasal resistance. Rhinology 16 : 243-249, 1978.

19) McCaffrey TV, Kern EB : Response of nasal airway resistance to hypercapnia and hypoxia in the dog. Acta Otolaryngol (Stockh) 87: 545-553, 1979.

20) McCaffrey TV, Kern EB : Response of nasal airway resistance to hypercapnia and hypoxia in man. Ann Otol Rhinol Laryngol 88: 247-252, 1979.

21）長谷川 誠：斎藤洋三，渡辺建介，高山 哲：息こら え」による鼻腔抵抗の変化について。日耳鼻 79: 30$35,1976$.

22) Salman SD, Procter DF, Swift DL et al: Nasal Resistance: Description of a method and effect of temperature and humidity changes. Ann Otol Rhinol Laryngol 80 : 736-743, 1971.

23) Dallimore NS, Eccles R: Changes in human nasal resistance associated with exercise, hyperventila tion and rebreathing. Acta Otolarygol (Stockh) 84: 416-421, 1977.

24) Cole P, Forsyth R, Haight JSJ : Effects of cold air and exercise on nasal patency. Ann Otol Rhinol 
Larygol 92 : 196-198, 1983.

25）谷本秀司, 石田祐子, 坂口喜清, 渡瀬隆雄, 奥田 稳： 温熱負荷による鼻腔通気度の変化. 日兽科 $24: 132$ ， 1985.

26) Hasegawa M, Kern EB: The effect of breath holding, hyperventilation, and exercise on nasal resis tance. Rhinology 16:243-249, 1978.

27) Richerson HB: Seebohm PM: Nasal airway response to exercise. J Allergy $41: 269-284,1968$.

28) Sakethhoo K, Kaplan I, Sackner MA : Effect of exercise on nasal mucous velocity and nasal airflow resistance in nomal subjects. J Appl Physiol Respirat Environ Exercise Physiol 46:369-371, 1979.

29) Forsyth RD, Cole P, Shephard RJ : Exercise and nasal patency. J Appl Physiol Respirat Environ Exercise Physiol 55: 860-865, 1983.

30) 饭倉洋治, 乾 宏行, 西川和子, 梅里義博: 運動誘発性 喘息. 医学のあゆ 123：393-400，1982。

31）長谷川 誠, 斎藤洋三, 渡辺建介, 高山 哲：鼻腔通気 度測定に関する研究の進歩。耳鼻 $21: 135-153$, 1975.

32) Fleiss JL: The design and analysis of clinical experiments. 1st Ed. John Wiley \& Sons, New York, 1986.

33) Conover WD, Iman RL: Rank transformation as a bridge between parametric and nonparametric statistics. The American Statintician 35 : 124-33, 1981.

34）佐久間 昭：医学統計Q＆A，金原出版，東京，1987.

35) Zwaardemaker $\mathrm{H}$ : Ademaanslag als diagnosticum der nasale stenose. Ned Tydschr Geneenk 25: 297 $-300,1889$.

36) Glatzel: Zur Plüfung der Luftdurchgängigkeit der Nase. Ther Gegenw 42: 348, 1901.

37) 白井信郎 他：呼吸抵抗計による綥腔抵抗測定法. 耳鼻 臨床 69: 1083-1089, 1976.

38）戸川 清 他：鼻腔通気測定法の現況. 耳鼻 26：665676,1980 .

39）堀部幸元 他：鼻腔通気度測定法の検討一オッシレー ション法による一，耳鼻臨床 $76: 1023-1030 ， 1983$.

40）戸川 清他:「舅腔通気度測定法の標準化」研究報告 集. 昭和52年度文部省科学研究費による試験研究, 1978.

41） 戸川 清 他：㜒腔通気度测定法の標準化. 昭和58年度 科学研究費補助金試験研究(1)研究成果報告書, 1984 。

42）戸川 清：鼻呼吸障害一その病態生理と臨床一，第83
回日耳国寛題報告, 1982

43）長谷川 誠，大木幹文：鼻腔抵抗值の測定法一基準点 のとり方について一，昭和58年度科学研究費補助金試 験研究(1)研究成果報告畫, 1984 .

44) Keuning J : On the nasal cycle. Int Rhinol 6: 99 .. 136, 1968.

45) Foxen EH et al: The assesment of nasal air-flow : A review of past and present methods. J Laryng and Otol 85: 811, 1971.

46）熊沢忠躬, 野村恭也：䁷科学臨床所見の定量化. 金原出 版, 東京, 1985 .

47）海野徳二 他：鼻空有効面積の測定について. 日耳鼻 76: 1060-1066, 1973 .

48）長谷川 誠：鼻腔抵抗測定法とその臨床的応用. 日耳 鼻 $76: 126-146 ， 1973$

49) Ingelstedt $S$ : Humidifying capacity of the nose. Ann Otol Rhinol Laryngol 79: 499, 1970.

50) Tonndorf W : Der Weg der Atemluft inder menschlichen Nase. Arch Ohren Nanen Kehl 146: 41, 1939.

51) Proetz AW : Air currents in the upper respiratory tract and their clinical importance. Ann Otol Rhinol Laryngol 60: 439, 1951.

52) Proctor DF : "Physiology of the upper airway" in Handbook of Physiology Vol 1. The Williams and Williams Co, Baltimore, 1960, pp. 309-345.

53) Rohler F : Der Stromüngswiderstand in den menschlichen Atenwegen und der Einfluss der unregelmässigen Verzuweigung des Bronchialsystems auf den Atmungsverlauf verschiedenen Lungenbezirken. Pflüg. Arch ges Physiol 162: 225, 1915.

54) Ohki M, Hasegawa $M$ : Studies of transnasal pressure and airflow values in a Japanese population. Rhinology 24 : 277-282, 1986.

55) Bachmann $W$ : The present status of rhinomanometry. Rhinology 14: 5-9, 1976.

56) Ferris BG, Mead J, Opie L: Partitioning of respimatory flow resistance in man. Appl Physiol $19: 4,1964$.

57）今野昭義：鼻内気流と鼾腔抵抗，第 2 編. 日耳舅 72 ： 49-65, 1969.

58) Jackson RT: Nasal-Cardiopulmonary refiexes: A role of the larynx. Ann Otol Rhinol Laryngol 85$70,1976$.

59) Eccles R, Lee L : The influence of the hypothalamus on the sympathetic innervation of the nasal vasculature of the cat. Acta Otolaryngol (Stockh) 
$91:$ 127-134, 1981.

60) Clement PAR: Committee report on standardization of rhinomanometry. Rhinology 22 : 151-155, 1984.

61）四宮敬介他：Exercise induced asthma (EIA) 誘発 に関わる運動の種類および量の検討，トレッドミルに よる運動負荷について.アレルギー 30：235-243. 1981 .

62) Hasegawa M, Kabasawa $Y$, Ohki $M$ et al : Exercise -induced change of nasal resistance in asthmatic children. Otolaryngol Head Neck Surg 93 : 772776, 1985.

63) Katz RM : Rhinitis in the athlete. J Allergy Clin Immunol 73 : 708-711, 1984.

64) Syabbalo NC, Bundgaard A, Widdicombe JG: Effects of exercise on nasal airflow resistance in healthy subjects and in patients with asthma and rhinitis. 507-513, 1985.

65）川村悟朗，飯倉洋治：スポーッとアレルギー、治療
$68: 101-106,1986$

稿を終えるに臨み，統計学的御指導を睗った佐久間昭東 京医科歯科大学臨床薬理学教授に深謝します. 小児科学的 にアドバイスを頂いた椛沢靖弘国立王子病院小児科医長に 深謝します．流体力学的に御助言をいただいた富永昭筑波 大学第一学群講師に感謝します。また, 直接御指導を賜つた 長谷川誠講師をはじめ, 東京医科菌科大学医学部耳鼻咽喉 科学教室員に深謝します。

本論文の要旨の一部は, 第22,23回の日本鼻科学会絰会に おいて発表し,さらに，第24回日本鼻科学会シンポジウムに おいてまとめて発表した。

本研究に対しては, 文部省科学研究費(奖励研究A, 課邀 番号62771303）の援助を受けた。

(原稿受付 昭和63.3.30日急載) 別刷請求先 $\overline{7} 351-01$ 和光市本町31-2-703 大棹文 